JAMILLE GREGÓRIO DOMBROWSKI

\title{
Associação entre Malária Gestacional, Restrição do Crescimento Intrauterino e Baixo Peso ao Nascer na Amazônia Extremo-Ocidental Brasileira
}

Tese de Doutorado apresentada ao programa de Pós-Graduação em Biologia da Relação Patógeno-Hospedeiro do Instituto de Ciências Biomédicas da Universidade de São Paulo para obtenção do título de Doutor em Ciências.

Área de Concentração: Biologia da Relação Patógeno-Hospedeiro

Orientador: Prof. Dr. Cláudio Romero Farias Marinho

Versão Corrigida. A versão original eletrônica encontra-se disponível tanto na biblioteca do ICB quanto na biblioteca digital de teses e dissertações da USP (BDTD). 
JAMILLE GREGÓRIO DOMBROWSKI

\section{Association between Gestational Malaria, Intrauterine Growth Restriction and Low Birth Weight in the Far-Western Brazilian Amazon}

PhD thesis submitted to the Postgraduate Program in Biology of the Pathogen-Host Relation of the Biomedical Sciences Institute of the University of São Paulo to obtain the title of Doctor of Science.

Area of Concentration: Pathogen-Host Relationship Biology

Advisor: Prof. Dr. Cláudio Romero Farias Marinho

Corrected version. The original electronic version is available in both the ICB library and the USP digital library of theses and dissertations (BDTD). 


\section{RESUMO}

Dombrowski JG. Associação entre malária gestacional, restrição do crescimento intrauterino e baixo peso ao nascer na Amazônia extremo-ocidental brasileira. [Tese (Doutorado em Parasitologia)]. São Paulo: Instituto de Ciências Biomédicas, Universidade de São Paulo; 2017.

A malária é uma doença parasitária grave e quando ocorre durante a gravidez é uma das principais causas de mortalidade materno-infantil, podendo apresentar como consequências anemia materna, aborto, nascimento prematuro, restrição do crescimento intrauterino e baixo peso ao nascer (BPN). A infecção por Plasmodium (P.) falciparum é reconhecida como um determinante importante de consequências sérias durante a gravidez e efeitos adversos semelhantes também foram relatados em infecções por $P$. vivax. A despeito de sua alta prevalência e a sua possível associação com importantes complicações durante a gravidez, os efeitos da malária para gestantes e seus conceptos ainda não estão totalmente compreendidos. Este trabalho propõe estudar as consequências da malária gestacional e sua associação com a restrição do crescimento intrauterino e baixo peso ao nascer em uma área endêmica no extremo oeste da Amazônia brasileira. Foi realizado um estudo retrospectivo e prospectivo composto por gestantes da região do Vale do Alto Juruá (Acre, Brasil), no qual foram avaliadas as consequências e a extensão do efeito da malária sobre o recém-nascido através da coleta de dados epidemiológicos e material biológico. Neste estudo, foi observado um aumento no número de partos prematuros e BPN entre os recém-nascidos das gestantes infectadas por $P$. vivax quando comparadas com o grupo não infectado. Em relação à infecção por $P$. falciparum durante a gravidez, observamos que a doença representou um fator de risco para o nascimento de neonatos com perímetro cefálico reduzido, assim como uma maior probabilidade de ocorrência de casos de microcefalia e nascimentos prematuros. Além disso, todos esses efeitos adversos estavam ligados à malária placentária, caracterizada principalmente por um aumento de agregados nucleares sinciciais e infiltrados inflamatórios, bem como um forte desequilíbrio dos fatores angiogênicos e diminuição dos níveis de leptina. Muitos estudos, realizados principalmente na África, destacam os efeitos deletérios da malária por $P$. falciparum no contexto materno-fetal, mas pouco se sabe sobre a malária gestacional nas áreas endêmicas da América, onde predominam as infecções por $P$. vivax. Nossos resultados sugerem que infecções por esta espécie estão longe de serem benignas em razão da alta incidência de lesões placentárias, baixo peso ao nascer, abortos e partos prematuro em nossa casuística. Além disso, este estudo também mostrou que a malária gestacional por $P$. falciparum aumentou a probabilidade de partos prematuros e a ocorrência da redução do perímetro cefálico nos recém-nascidos, o que está associado à malária placentária. Assim, o conhecimento do impacto da infecção sobre a placenta e no desenvolvimento fetal poderá trazer uma importante contribuição para o entendimento da malária gestacional, além de possibilitar o desenvolvimento de ações específicas na rotina de cuidado pré-natal.

Palavras-chaves: Malária. Malária gestacional. Gestação. Baixo peso ao nascer. Restrição do crescimento intrauterino. 


\begin{abstract}
Dombrowski JG. Association between gestational malaria, intrauterine growth restriction and low birth weight in the far-western Brazilian Amazon. [Ph. D. Thesis (Parasitology)]. São Paulo: Instituto de Ciências Biomédicas, Universidade de São Paulo; 2017.

Malaria is a severe parasitic disease that, when occurs during pregnancy, it is one of the main cause of maternal-fetal mortality leading also to maternal anemia, abortion, preterm birth, intrauterine growth restriction and low birth weight. Infections by Plasmodium (P.) falciparum are known to be detrimentally involved in poor pregnancy outcomes, effects that were also described during $P$. vivax infections. Despite its significant prevalence and possible association to severe complications during pregnancy, the impact of malaria in pregnant women and their children are not clearly understood. Current study aims to evaluate the consequences of malaria in pregnancy and correspondent association with intrauterine growth restriction and low birth weight in an endemic area located in the furthest west region of the Brazilian Amazon. A retrospective and prospective study was performed, accounting with pregnant women living in the region of Vale do Alto Juruá (Acre, Brazil) in which the consequences and extension of malaria effects on the newborns was evaluated through the analysis of epidemiological data and biological material. In this study, we observed an increase in the number of preterm deliveries and low birth weight among children born from pregnant women infected with $P$. vivax when compared to noninfected pregnant women. Regarding $P$. falciparum infection during pregnancy, we have noticed that this is a risk factor for newborns with reduced head circumference, also increasing the probability of occurring cases of microcephaly and preterm birth. Besides, every deleterious effect was associated with placental malaria, which is mainly characterized by an increase in the syncytial nuclear aggregates and inflammatory infiltrates, as well as by an imbalance in placental angiogenic factors and a reduction in leptin levels. Several studies mainly developed in Africa, highlight the negative effects of $P$. falciparum malaria in the maternal-fetal context yet, little is known about malaria in pregnancy that occurs in the endemic areas of the America where infections caused by $P$. vivax are predominate. Our results suggest that infections promoted by this parasite species are far from being benign as it was depicted in our cohort, which has shown high incidence of placental lesions, low birth weight, abortion and preterm delivery. Moreover, the present study has shown that malaria in pregnancy caused by $P$. falciparum increased the probability of preterm delivery and reduction of head circumference in newborns, which is associated to placental malaria. Therefore, knowing the impact of infection in the placenta and fetal development may bring an important contribution to the understanding of malaria in pregnancy, allowing the development of specific action that can be implemented in the routine of antenatal cares.
\end{abstract}

Keywords: Malaria. Malaria in pregnancy. Gestation. Low birth weight. Intrauterine growth restriction. 


\section{INTRODUCTION}

\subsection{Human development}

The human development is a complex process that starts with fecundation, when the male gamete (spermatozoon) merging with the female gamete (oocyte) originates the zygote, the cell that represents the onset of a new being $(1,2)$. The 23 Carnegie stages of human embryonic development reflect the set of alterations during the first eight weeks (60 days) of development, mainly based on the fulfillment and the external features of the embryo (Figure 1) (2).

Figure 1 - Carnegie stages of human development in the first 8 weeks.

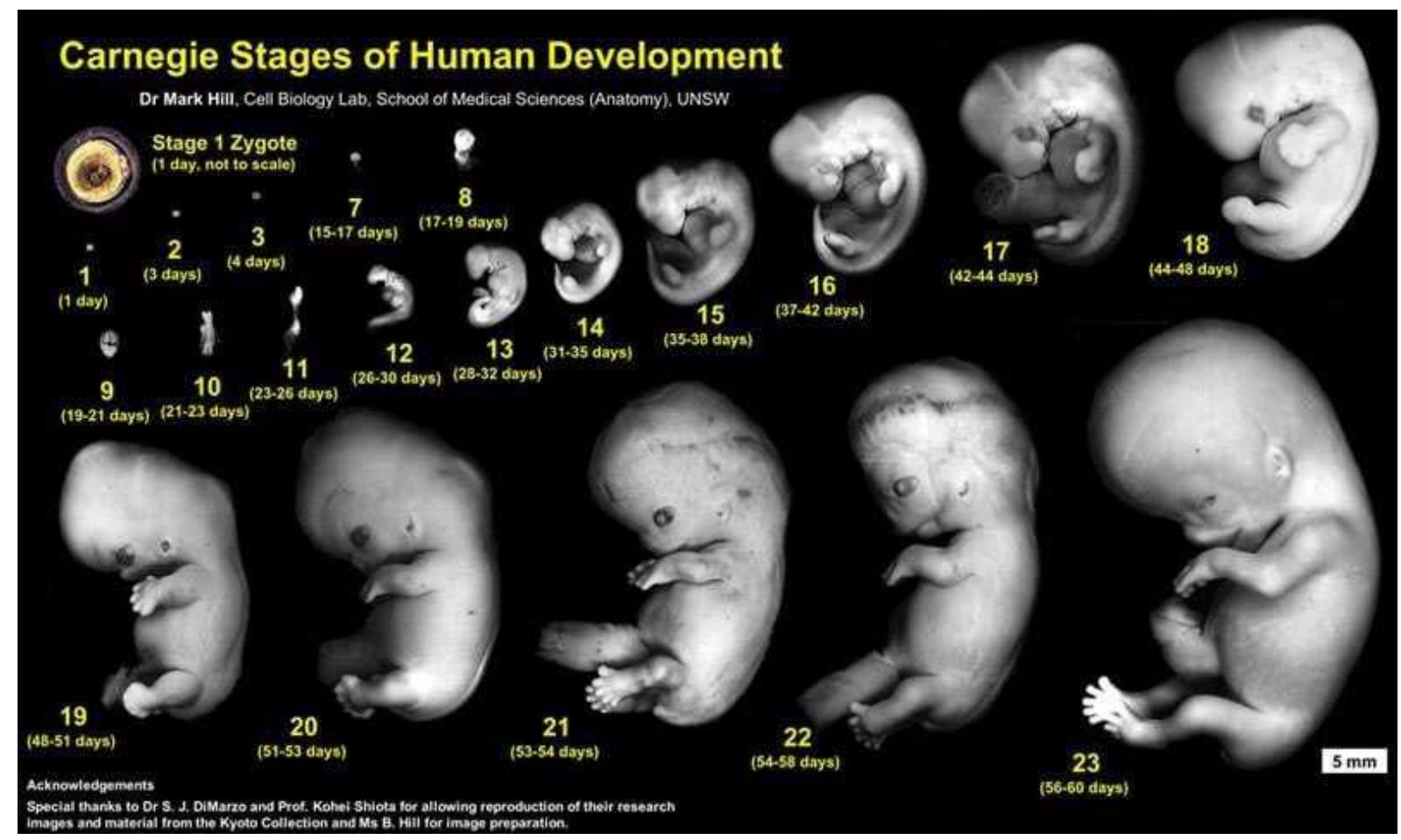

White bar represents a scale of 5 millimeters $(\mathrm{mm})$ and all embryos are in proportion. Source: Hill MA, 2004 (3).

In short, those development stages are grouped in weeks, and they can be characterized by the relevant events in each period. The end of the first week of development is marked by the superficial implantation of the egg (blastocyst) in the endometrial stroma. The second week is characterized by the full implantation of the egg and the settlement of the primitive uterine placental blood circulation. Added to this, it occurs the formation of the bilaminar germinal disc constituted by the epiblast 
(embryonic ectoderm) and the hypoblast (embryonic endoderm). During the third week, the most characteristic event is the gastrulation process, where the three germinal layers of the embryo (ectoderm, mesoderm and endoderm) are set (Figure 2). Thus, through such process, the epiblast cells originate every germinal layer, and the cells from that layer give origin to all the tissues and organs of the embryo) $(1,2)$.

Figure 2 - Germ layers - A gastrula forms 3 primitive germ (tissue) layers.

\begin{tabular}{|l|l|l|}
\hline \multicolumn{1}{|c|}{$\begin{array}{l}\text { Embryonic } \\
\text { Germ Layer }\end{array}$} & \multicolumn{1}{c|}{ Vertebrate Adult Structures } \\
\hline $\begin{array}{l}\text { Ectoderm } \\
\text { (outer layer) }\end{array}$ & $\begin{array}{l}\text { Nervous system; epidermis of skin; } \\
\text { epithelial lining of oral cavity and rectum }\end{array}$ \\
\hline $\begin{array}{l}\text { Mesoderm } \\
\text { (middle layer) }\end{array}$ & $\begin{array}{l}\text { Musculoskeletal system; dermis of skin; } \\
\text { cardiovascular system; urinary system; } \\
\text { reproductive system; outer layers of } \\
\text { respiratory and digestive systems }\end{array}$ \\
\hline $\begin{array}{l}\text { Endoderm } \\
\text { (inner layer) }\end{array}$ & $\begin{array}{l}\text { Epithelial lining of digestive tract and } \\
\text { respiratory tract; associated glands of these } \\
\text { systems; epithelial lining of urinary bladder }\end{array}$ \\
\hline
\end{tabular}

Source: The McGraw-Hill Companies (4).

The embryonic period comprises all the events that occur until eighth week of gestation, which is also known as organogenesis. During that period, the division and specialization of the cells takes place, originating the main organic systems and organs in the body. It is noteworthy that two important systems are the first to begin their formation in this stage: the process of neurulation, which will later form the central nervous system and cardiovascular system, which will be the body's first system to achieve function at the end of the embryonic period $(1,2,5)$. Such phase is characterized by making recognizable the main external features of the body shape affecting the look of the concept, which will be acquiring human appearance (Figure 3) $(2,5)$.

As the beginning of every essential structure happens along the embryonic period, this is a critical phase to the human development, since it is the phase where the embryo can be exposed to teratogen or infectious agents, which can lead to several congenital malformations, causing severe development problems (2). 
Figure 3 - Schematic diagram of critical periods of human development.

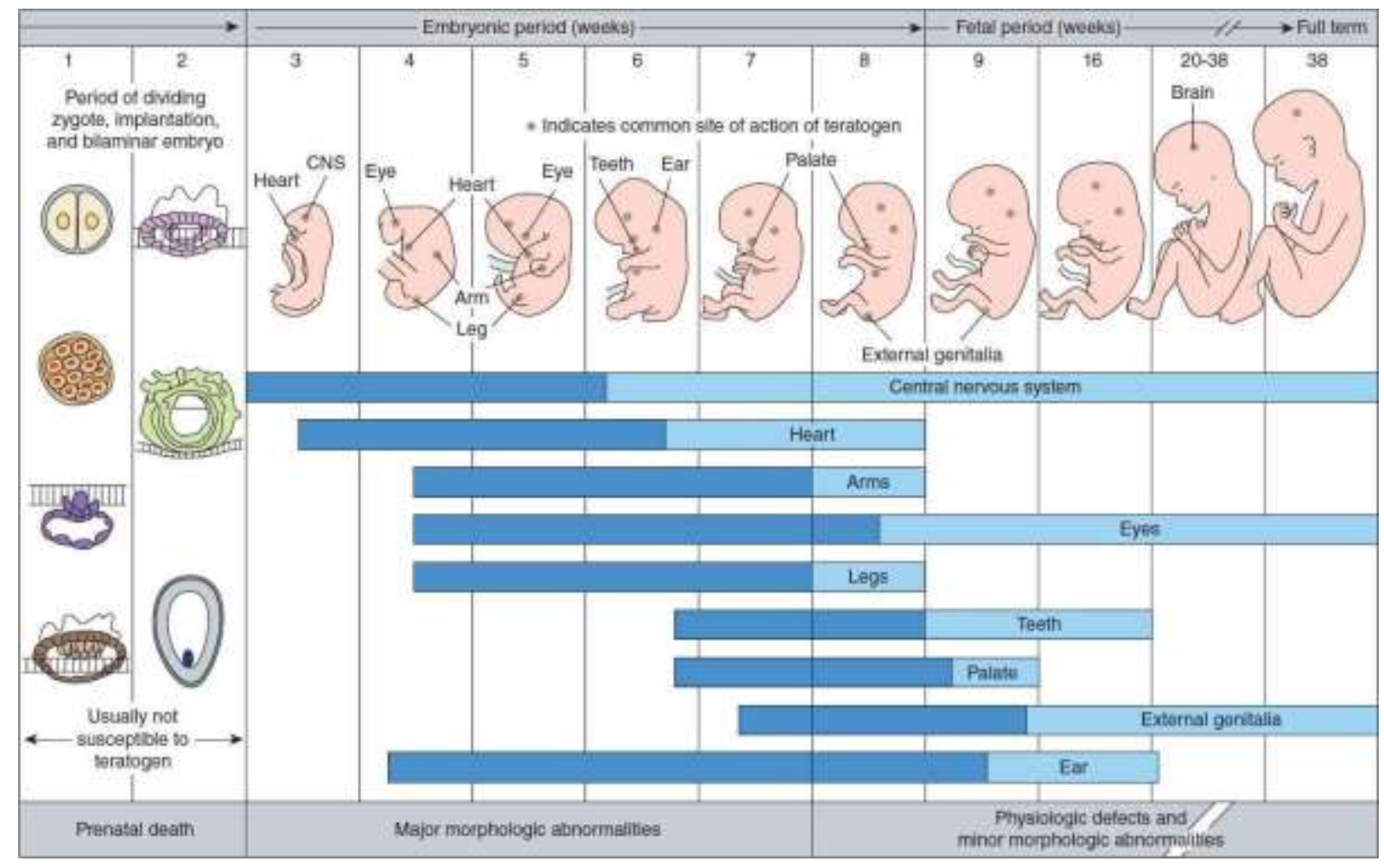

Each organ or structure has a critical period when it is most sensitive to damage from teratogens or infectious agents. The dark blue portion of the bars represents the most sensitive periods. The light blue portion of the bars represents periods of development during which physiological defects and minor structural abnormalities would occur. Source: Adapted from Moore KL, 1993 (5).

From the ninth week onwards, when the embryo already has human appearance, it is denominated fetal period. This period of development is characterized by a fast body growth, added to the maturity of tissues and organs formed in the embryonic phase (Chart 1) $(1,2,5,6)$. Along the third, fourth, and fifth gestational months, the growth by length is more noticeable, while during the two last months it is marked by an increase in the fetal weight (1). It is important to point out that several organs and tissues do not develop in an identical pace nor reach a maturity level at the same time. The full-term fetus has the digestive, respiratory, circulatory and urinary systems practically ready for the extra uterine life, while the nervous and bone systems remain immature and their differentiation still continue for months after the birth (2). 
Chart 1 - Summary of the main events during the fetal period

\begin{tabular}{|c|c|}
\hline $\begin{array}{l}3^{\text {rd }} \text { month } \\
\left(9^{\text {th }} \text { to } 12^{\text {th }} \text { week }\right)\end{array}$ & $\begin{array}{l}\text { The face becomes more human and there is a relative decrease } \\
\text { in the head growth in relation to the body; the ossification starts } \\
\text { with the presence of the long bones and the skull, the primary } \\
\text { ossification centers; the external genitalia of the fetus is still } \\
\text { undifferentiated until the end of the } 9^{\text {th }} \text { week, and its mature } \\
\text { form is only set at the } 12^{\text {th }} \text { gestational week; beginning of the } \\
\text { fetal moves, but they are imperceptible by the mother due to its } \\
\text { small size; fetal circulation is complete. }\end{array}$ \\
\hline $\begin{array}{l}4^{\text {th }} \text { month } \\
\left(13^{\text {th }} \text { to } 16^{\text {th }} \text { week }\right)\end{array}$ & $\begin{array}{l}\text { Very fast growth, especially of the body; onset of the } \\
\text { ossification centers for the remaining bones under the X-Rays, } \\
\text { started in the } 16^{\text {th }} \text { week; Nasal septum and palate close. }\end{array}$ \\
\hline $\begin{array}{l}5^{\text {th }} \text { month } \\
\left(16^{\text {th }} \text { to } 20^{\text {th }} \text { week }\right)\end{array}$ & $\begin{array}{l}\text { Fetal moves start being perceptible by the mother; onset of the } \\
\text { multilocular fat tissue, specialized in the production of heat; } \\
\text { from the } 20^{\text {th }} \text { week onwards, it appears the lanugo and hair, and } \\
\text { the skin is covered by a caseous varnish, a material constituted } \\
\text { by the greasy secretion from the sebaceous glands, which have } \\
\text { the purpose to protect the fetal epidermis. }\end{array}$ \\
\hline $\begin{array}{l}6^{\text {th }} \text { month } \\
\left(21^{\text {st }} \text { to } 24^{\text {th }} \text { week }\right)\end{array}$ & $\begin{array}{l}\text { Accentuated gain of weight; erythropoiesis in the spleen; } \\
\text { although every organ is developed and several systems are } \\
\text { able to function, the fetus is still unable to survive in the extra } \\
\text { uterine life, mainly due to the immaturity of the respiratory } \\
\text { system, despite the surfactant production. }\end{array}$ \\
\hline $\begin{array}{l}7^{\text {th }} \text { month } \\
\left(25^{\text {th }} \text { to } 28^{\text {th }} \text { week }\right)\end{array}$ & $\begin{array}{l}\text { The erythropoiesis starts occurring in the bone marrow; the } \\
\text { fetus is able to conduct the rhythmic respiratory moves and to } \\
\text { control the body temperature; skin is red; eyes open and close. }\end{array}$ \\
\hline $\begin{array}{l}8^{\text {th }} \text { and } 9^{\text {th }} \text { months } \\
\text { (29 } 9^{\text {th }} \text { to birth) }\end{array}$ & $\begin{array}{l}\text { The fetus acquires more rounded contours resulting from the } \\
\text { deposition of subcutaneous fat; spontaneous orientation } \\
\text { towards the light; loss of the lanugo; amniotic fluid decrease; } \\
\text { vigorous fetal movement occurs; fetus is viable. }\end{array}$ \\
\hline
\end{tabular}

Source: Adapted from: Sadler TW, 2016 (1); Montenegro CAB, Rezende Filho J, 2014 (2); Moore KL, Persaud TVN, 1993 (5); Montari T, 2013 (6). 
Then, birth occurs 280 days (40 weeks) after the first day of the last menstruation (regular 28 day cycles) or in a more precise way, 266 days (38 weeks) after fertilization (1). Thus, in a general way, growth patterns and fetal development can be divided in three parts, according to gestational ontogeny: (i) in the first trimester, occurs the organogenesis; (ii) in the second trimester, the fetus undergoes a major increase in body size and cell hyperplasia with a simultaneous cellular adaptation, and (iii) the maturity of the organs and cellular hypertrophy along the third trimester (7).

The intrauterine growth and development can be impaired by a series of factors such as nutritional deficiency, use of alcohol, drugs, and smoke, infections (viral, bacterial or parasitic) and placental insufficiency caused by the above or several other factors. With this, the impact of an adverse effect on the intrauterine environment and in fetal growth depends on the nature and time of exposure to that insult $(8,9)$ in which the physical condition at birth, post-natal growth and resulting development will be different (10).

\subsection{Placenta}

Human placenta starts its development at the sixth day after conception with the implantation of the blastocyst on the endometrium. The placenta is considered a mixed and interactive organ and is characterized by being a transient organ with a discoid format, villous, and hemomonochorial $(2,11,12)$. Its main functions are metabolic, endocrine, and to promote the exchange of nutrients, gases and metabolites between the mother and the fetus, besides providing physicalmechanical protection, also acting as an immunological barrier $(2,11,12)$. Its approximate dimensions are 15-20 cm long, and 1-3 cm thick (with larger thickness in the center, becoming peripherally thinner), with weight ranging from 500 to 600 grams, representing around $1 / 6$ of the weight of the fetus (12).

The human placenta is formed by a fetal portion (originated in the villous chorion or chorionic plate) and a maternal portion (decidua basalis), which is formed by modifications in the uterine endothelium induced by the implementation of the blastocyst, corresponding to the functional layer of the pregnant endometrium to be eliminated at birth (2) (Figure 4). Three different decidua regions can be identified, and they are denominated according to their relationship with the site of implantation: 
(i) Decidua basalis: it is the portion of the decidua farther from the concept, forming the maternal component of the placenta; (ii) Capsular decidua: this is the superficial portion of the decidua covering the concept; and, (iii) Parietal decidua: constituted by all the remaining portions of the decidua (12).

Figure 4 - Schematic representation of the human placenta.

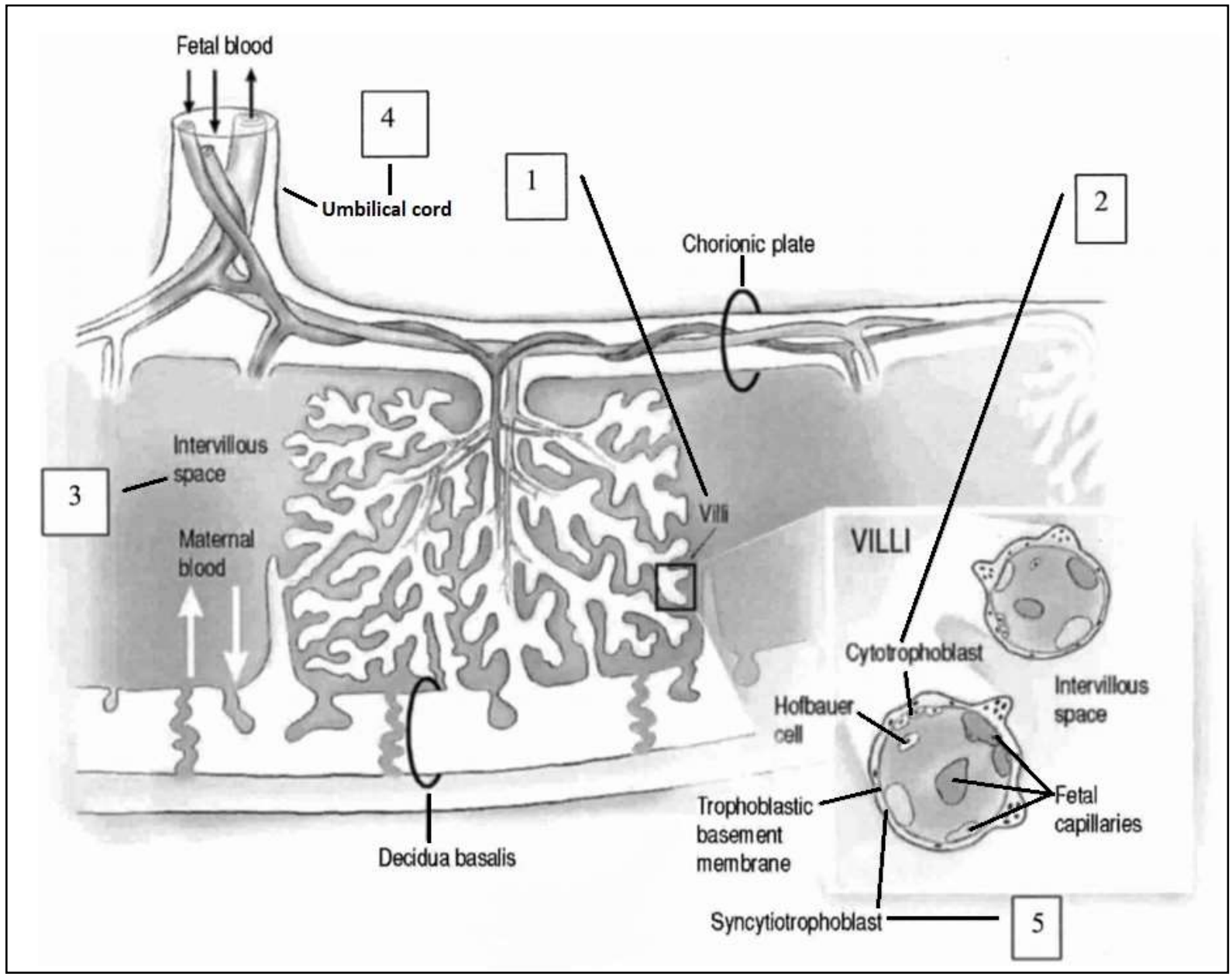

(1) The villi are composed by fetal connective tissue and are covered by trophoblasts, which is the placental parenchyma and it is where maternal-fetal exchanges must occur. (2) The cytotrophoblast is made of distinctly separated cells that form a continuous layer in early pregnancy responsible for the invasion into the decidua and the myometrium; later in pregnancy, this layer is reduced to a few scattered large pale cells with pale nuclei. (3) Placental villi are in the intervillous space and are bathed in blood from the maternal vessels. (4) Umbilical cord inserted into the fetal side of the placenta, composed of two arteries and one vein where fetal blood flows. (5) The syncytiotrophoblast forms an external layer covering of the villi, a syncytium with many dark-staining nuclei. During the latter half of pregnancy, groups of aggregated nuclei may project at the surface forming syncytial nuclear aggregates. Chorionic plate on fetal face and basal decidua on maternal face. Source: Adapted from McGready R. et al., 2004 (13). 
Further to those structures, the placenta still has the chorionic plate and the villous chorion, corresponding to the fetal contribution to form the placenta (11). The stem-villi originated from it protrudes inside the intervillous space, containing the maternal blood inside it (12). Histologically, the chorionic villi are formed by a central stem of conjunctive nature, where the fetal vessels are located, covered by the cytotrophoblast and syncytiotrophoblast. Those two types of cells compose the structure of the chorionic villi (14). The syncytiotrophoblast is more abundant, forming the external surface of the villi, which is in direct contact with the maternal blood. It is characterized by presenting multinucleate cells, which are organized in a layer of variable thickness (11). The cytotrophoblast cells are in a smaller amount, and they are located just below the syncytiotrophoblast. Under the microscope, the cytotrophoblast cells are easily identified: they have a rounded format, round nucleus, and a looser chromatin than those composing the syncytiotrophoblast (Figure 5). It can also be observed in those cells mitosis that do not appear in the syncytiotrophoblast (11).

Fetal blood passing by the villi vessels performs the exchanges with the maternal blood circulating in the intervillous space, bathing the villi. While pregnancy evolves, the number of vessels in the villi increases, and the mesenchyme tissue decreases, thus facilitating maternal-fetal exchanges. In the chorionic plate, it is still found the umbilical cord, which is a tube connecting the maternal organism to the body of the developing fetus. The umbilical cord is constituted by two arteries responsible by carrying nutrients and $\mathrm{O}_{2}$ to the fetus, and a vein responsible for returning the metabolite excreta and $\mathrm{CO}_{2}$ to be metabolized in the maternal organism (12). 
Figure 5 - Histological image of the human placenta.

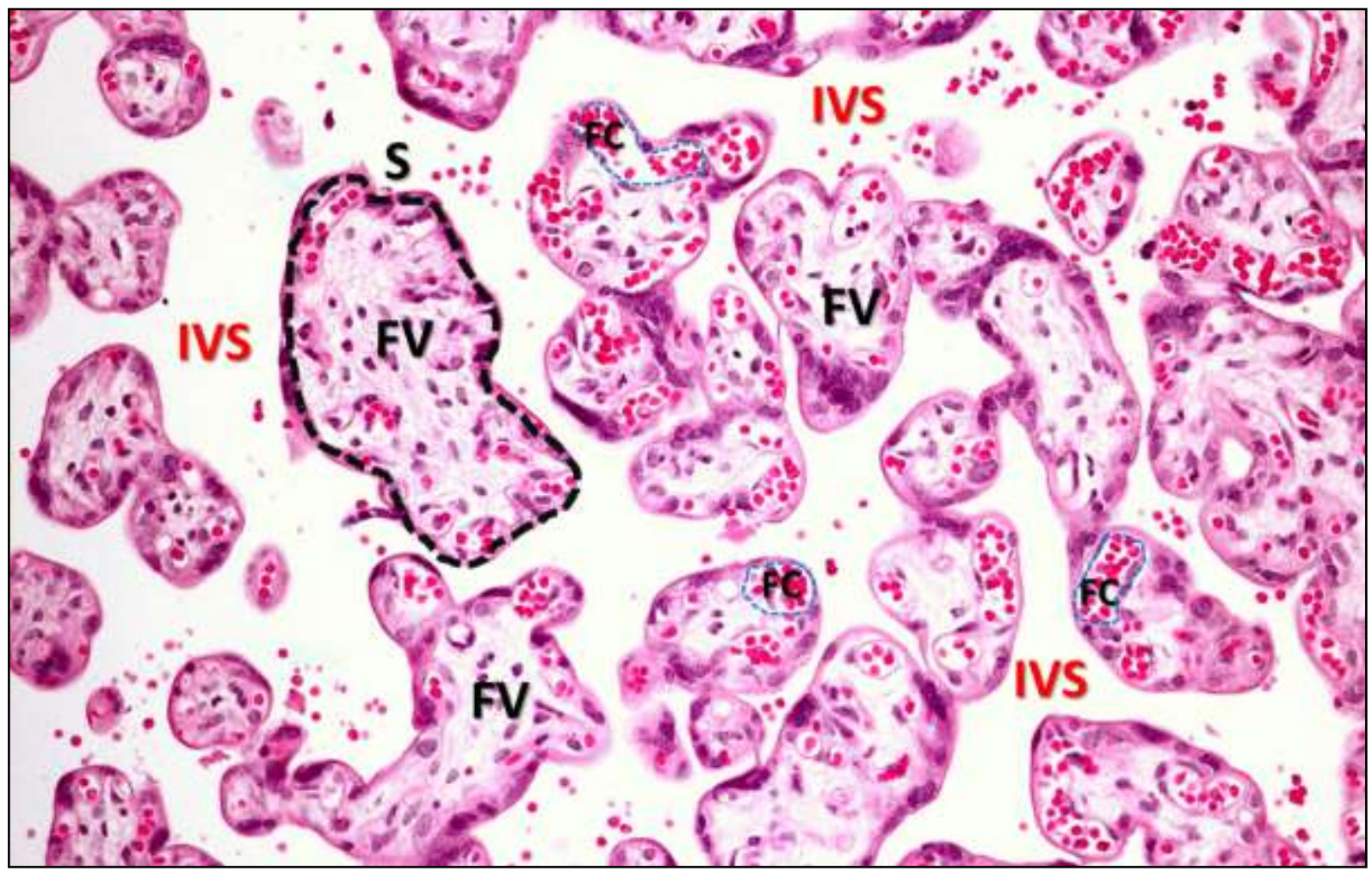

Image made in optical microscope, 10x, H\&E, showing intervillous space (IVS), fetal villi (FV) and fetal capillaries (FC). Source: made by Rodrigo Medeiros de Souza.

Placental vascular development and uterine vascular adaptation during pregnancy enable the appropriate supplying of nutrients and substrates for fetal development. Any disturbances in the development of the villi-tree have been associated to the abnormal intrauterine development and perinatal mortality (15). With this, the correct transportation of nutrients and gases to the fetus through the placenta is extremely important. Presently, it has been the aim of several studies, in which scientists try to establish a possible association between the weight of the fetus at the moment of birth and its susceptibility for cardiovascular diseases, diabetes, hypertension, and other diseases along the adult life (16-21).

\subsection{Low birth weight and intrauterine growth restriction}

The newborn weight is considered one of the main factors determining the probability of survival to the neonatal period and even along the remaining first year of life (22). Low birth weight (LBW) is defined, by the World Health Organization (WHO), as weight at birth less than $2500 \mathrm{~g}$, regardless gestation age. Other 
classifications can also be considered: very LBW (lower than 1500g) and extreme LBW (lower than 1000g) (23). Low birth weight has a multifactorial genesis, being the prematurity (birth before the 37th gestational week) and intrauterine growth restriction (IUGR) the major factors that may actuate in an isolated or combined way, determining a weight that is lower than the normal (24).

The incidence of newborns with low weight is directly affected by the same factors that influence the health of the population in which it is inserted, such as sanitation, nutrition, perinatal care, social-economic status, infections, comorbidities as hypertension, etc. (25). LBW is strongly associated with neonatal morbimortality, growth and cognitive development inhibition in children and chronic diseases in their adult life. Currently, more than to 20 million children born with low weight all over the world, from which $95.6 \%$ in developing countries. In South America, 9.6\% of newborns have LBW (25).

IUGR is defined as the incapacity of a fetus to keep the expected growth, with an estimated birth weight below $10 \%$ in the intrauterine growth curve for the gestational age $(26,27)$. The perinatal mortality rate in newborn with IUGR can attain a 20 times higher level than in babies with a normal growth (8). IUGR appears in 5$10 \%$ of pregnancies, and it is associated to morbidity and mortality during the perinatal and childhood periods (28). Added to that, IUGR is related to cardiovascular and metabolic diseases in the adult life (29).

Fetus incapacity to achieve its genetically determined size can occur due to several causes and/or several pathological pathways, most of them are unclear or even totally unknown (30). The main determinant for intrauterine growth in the beginning of the pregnancy is the genome, but in the next phases of development, such growth begins to be influenced by several other immunological, nutritional, environmental, and vascular factors. Hence, the occurrence of IUGR can be due to any disturbance in one of those factors along pregnancy (20).

The moment of gestation in which the growth occurs below the expected differentially reflects future changes in body symmetry and anthropometric indexes, including the cephalic perimeter, biparietal diameter, and abdominal circumference, and they can be classified after birth based on the Rohrer Ponderal Index (8). Thus, IUGR can be basically divided in three groups $(8,10,20,31)$ : 
- Type I IUGR: In a general way, it occurs in $20 \%$ of the cases, and it is resulting from etiologic factors (maternal infections, chromosome alterations, congenital malformation) actuating in the beginning of pregnancy. In general, the below ideal growth in the first and beginning of the second trimester produces proportional newborns, although small for their gestational age due to the reduced cellular hyperplasia. It is known as intrinsic or proportional symmetric growth restriction, where length, weight, and cranial circumference are proportionally damaged.

- Type II IUGR: The newborns in whom the growth restriction occurred later in pregnancy, the growth indexes are out of proportion, as they affect cellular hypertrophy phase, and they are considered as having suffered asymmetrical growth restriction, most of times caused by placental insufficiency. This type of growth restriction can occur in $75 \%$ of cases and, as consequence, there is a reduction in the abdominal circumference, as it affects mainly the liver, as its growth is affected by the higher glycogen consumption. Thus, those babies have preserved length and cranial circumference, but low weight.

- Type III IUGR: This type of growth restriction occurs in 5 to $10 \%$ of the cases, and it is considered an intermediate type, since it is a consequence of an aggression process both in the hyperplasia phase and in the hypertrophy of the cellular growth phase. The main etiologic factors can be maternal malnutrition, use of illegal substances, and abusive use of alcohol and smoke. In general, the newborns are basically classified as type I or II, since the differentiated clinical diagnosis of the type III is quite difficult.

The low weight and growth restriction diagnosis can be performed in two ways: intrauterine or post-natal. The intrauterine diagnosis performed through obstetric serial ultrasound is the main method used for the early detection of the problem, and it uses, as assessment mean, the biparietal diameter, the relationship between cranial and abdominal circumferences, the femur length, and the total intrauterine volume. Other resources can also be used, such as fundal height measurement, which is the easier and most accessible method, although a little 
sensitive, requiring a qualified professional, in addition to the biochemical dosage of substances in the amniotic fluid. Finally, the post-natal diagnosis is basically performed through the correct assessment of the gestational age at birth. In the absence of ultrasound examination, which is performed in the first trimester or along pregnancy, use other methods are used based on the assessment of the somatic and neurological features of the newborn, such as Dubowitz and Ballard score, and the assessment through the intrauterine growth curves used in the neonatal diagnosis of the fetal growth adequacy $(10,32,33)$.

\subsection{Malaria and Plasmodium life cycle}

Malaria is the most incident parasitic disease in the world, being one of the most important public health issues in the present days. This infection, one of the oldest parasitary diseases ever recorded, is caused by a mandatory intracellular protozoan of the Plasmodium genus pertaining to the Apicomplexa phylum. Up to this moment, it has been described more than 200 species of Plasmodium (34), among them the ones infecting birds, rodents, reptiles, non-human primates, and humans. The species causing the disease in human are Plasmodium ( $P$.) vivax, $P$. falciparum, $P$. malariae, $P$. ovale (35), P. cynomolgi (36) and $P$. knowlesi (37).

The disease is transmitted to humans through the bite of an infected female mosquito of the Anopheles genus. As such, the biology of the parasite includes a life cycle in a vertebrate intermediate host and in a definitive invertebrate host (38). Depending on the parasite genus, each Plasmodium has a disease cycling with specific features.

In a general way, the biological cycling of malaria in human is summarized in two phases: pre-erythrocytic cycling (including the liver stage) and the blood cycling (Figure 6). The pre-erythrocytic cycling has its onset when an Anopheles female takes a blood meal, innoculating sporozoites present in its saliva. Those forms cross the subcutaneous tissue of the host, and after entering into the blood circulation, they make their way to the liver, where they penetrate into the hepatocytes to produce the schizonts (schizogony tissue), originating thousands of merozoites (36). This hepatic phase of the cycle is asymptomatic, and it lasts in average 6 to 14 days, corresponding to the incubation period of the parasite. The merozoites that are released from the hepatocytes, probably in the form of small vesicles known as 
merossomes (39), will invade the erythrocytes (starting the erythrocitic cycling) developing themselves into trophozoites, that will form blood schizonts by nuclear division. During that phase, the infected erythrocite shows on its surface proteins from the parasite that will mediate adhesion to the host tissues (40).

Figure 6 - Lifecycle of Plasmodium in the human body and in the mosquito.

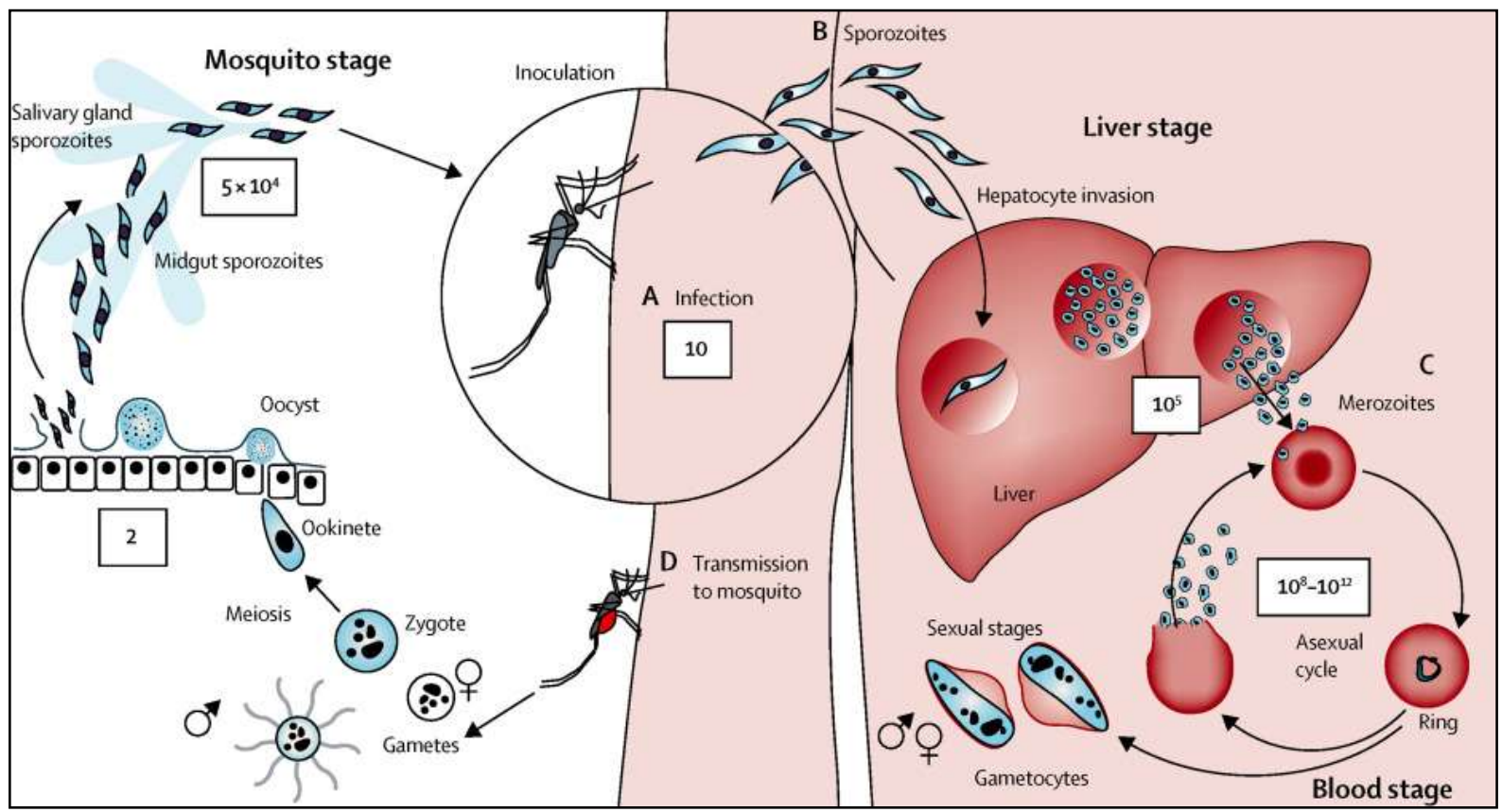

(A) The cycle in human begins with the inoculation of sporozoites into the dermis, (B) which then travel to the liver; each sporozoite invades a hepatocyte and then multiplies. (C) After one or two weeks, the liver schizonts burst, releasing into the bloodstream thousands of merozoites that invade erythrocytes, beggining the asexual cycle. Some parasites develop into sexual forms (gametocytes), (D) which are taken up by a feeding Anophelis mosquito. This is when sexual reproduction occurs inside the mosquito gut, forming ookinetes and then oocysts. The oocyst bursts and liberates sporozoites, which migrate to the salivary glands to await inoculation at the next blood feed. Source: White NJ et al., 2014 (41).

The most important phenotypic characteristic of Plasmodium is its ability to penetrate into red blood cells by releasing proteins contained in an apical complex, which occurs in a similar way to the hepatocytes penetration by sporozoites (36). When the schizonts are fragmented, they disrupt the blood cells and release new merozoites into the blood circulation. Some merozoites from the blood schizogony will result in gametocytes, the sexual form of the parasite, responsible for infecting the vector (42).

It is along the multiplication, invasion, and rupture cycling that the clinical simptoms of malaria are felt, and it may be either gradual or fulminanting (42). The first symptoms of malaria are non-specific and similar to a systemic viral disease that 
include tiredness, discomfort, abdominal fadigue, muscular and articular pain, followed by headache, fever, chills (the malarial triad), sudoresis, anorexia, vomit, and malaise $(42,43)$. Disease clinical manifestation can be influenced by parasite and host genetics, patient age, parasite species, and the region's transmission intensity, making the manifestations to range from asymptomatic to severe or fatal $(44,45)$.

\subsection{Epidemiology of malaria}

\subsubsection{Malaria in the world}

The real incidence of the malaria in the world is an innacurate information. In the last few years, the disease has been concentrated in the tropical and subtropical regions, where it is mainly gathered in developing countries that have deficits in their health information systems (46). According to the last Malaria Report published by the WHO in 2016, up to 148 to 304 million cases were reported and approximately 429,000 deaths were resgitered in the whole world (47).

Among all parasite species infecting humans, the $P$. falciparum and $P$. vivax are the most prevailing, and they are widely distributted in every endemic region in the world (Figure 7), posing a severe public health issue in more than 100 countries (41). In 2015, around $90 \%$ of malaria cases in the world occurred in the African continent, where infections are almost exclusively attributted to $P$. falciparum, the most prevailing species in that region (47).

The infections caused by $P$. vivax represent approximately $4 \%$ of the global cases notified, but outside the African continent, such proportion increases above $40 \%$. The Asian Southwest region accounts for the highest amount of cases with around $58 \%$ of the infections caused by the parasite. In the Americas, infections by the $P$. vivax represent around $70 \%$ of cases (47), and Brazil is responsible for the highest amount of cases. 
Figure 7 - Distribution map of malaria transmission risk areas.

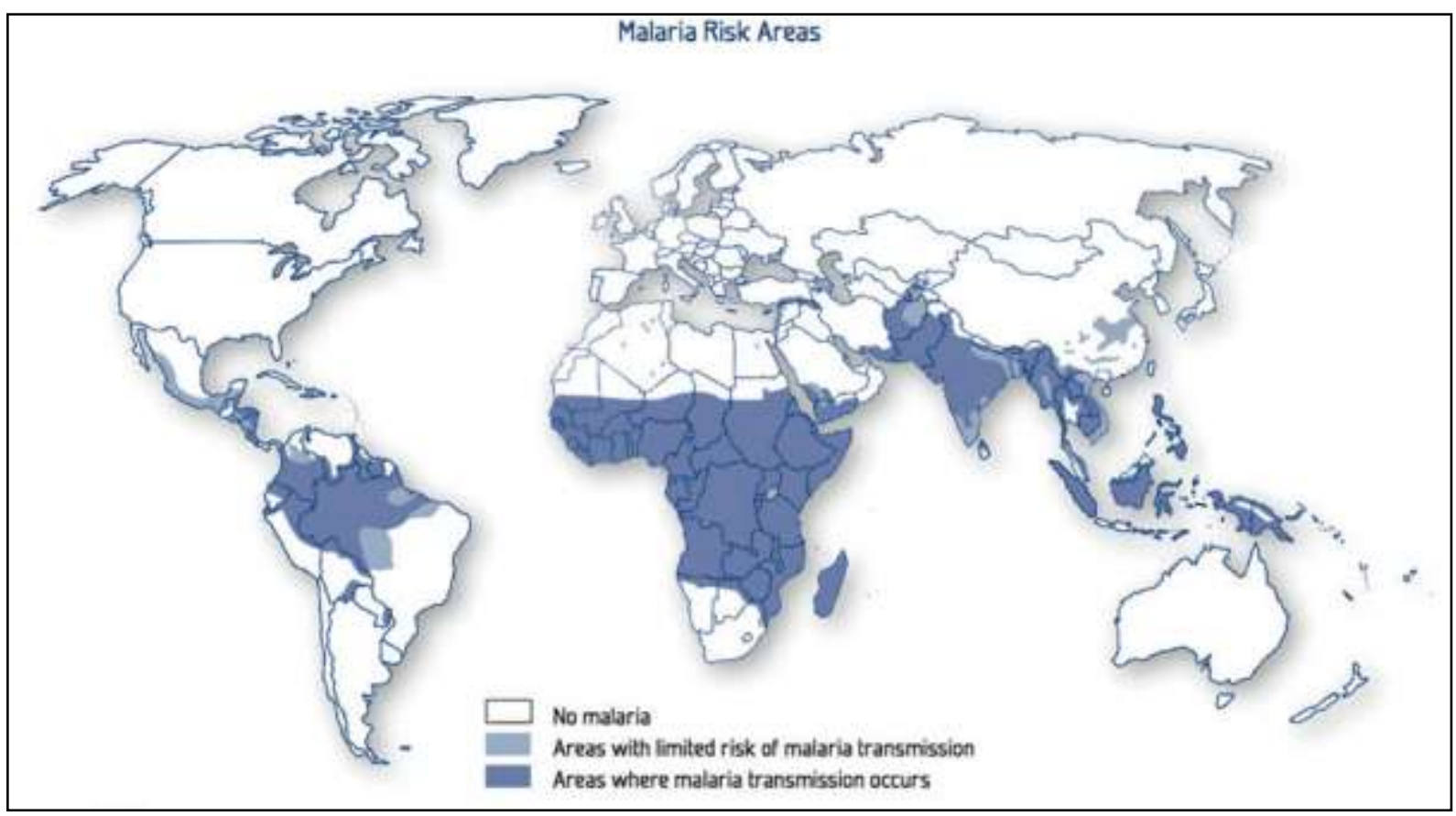

Source: Scott Filler|Malaria, 2017 (48).

It is estimated that each year, above 3 billion people are exposed to malaria, and despite a $22 \%$ reduction in the number of fatal cases since 2010 , the proportion of deaths is still high, despite being caused by a treatable disease which easy to prevent. The fatal cases of the disease are mainly related to infections by the $P$. falciparum (99\%) and, in general, they are concentrated in the sub-Saharan Africa. Nevertheless, it is worth to point out that outside the African continent, $P$. vivax was responsible for approximately $86 \%$ of all deaths caused by malaria in 2015 . During that same year, $70 \%$ of the total deaths were only children below 5 years (47). But besides children, other populational groups face a high risk of dying with malaria, such as travellers, immunodefficient individuals, and pregnant women $(49,50)$.

\subsubsection{Malaria in Brazil}

In Latin America, Brazil is responsible for the highest amount of malaria cases, in which it remains among the main parasitic endemic diseases in the country. According to the Health Surveillance Secretariat in 2014, it has been notified around 145 thousand cases all over the country, and 99\% of them were concentrated in the Legal Amazon states (Figure 8). In Brazil, only three parasite species are associated 
to the autochthonous cases of the disease: $P$. vivax, $P$. falciparum and $P$. malariae. Infections caused by $P$. vivax prevail in the country, accounting for up to $84 \%$ of cases, followed by the infections caused by $P$. falciparum, which correspond to $16 \%$ of the notified cases in 2014 (51).

Figure 8 - Distribution map of malaria transmission risk areas in Brazil in 2015.

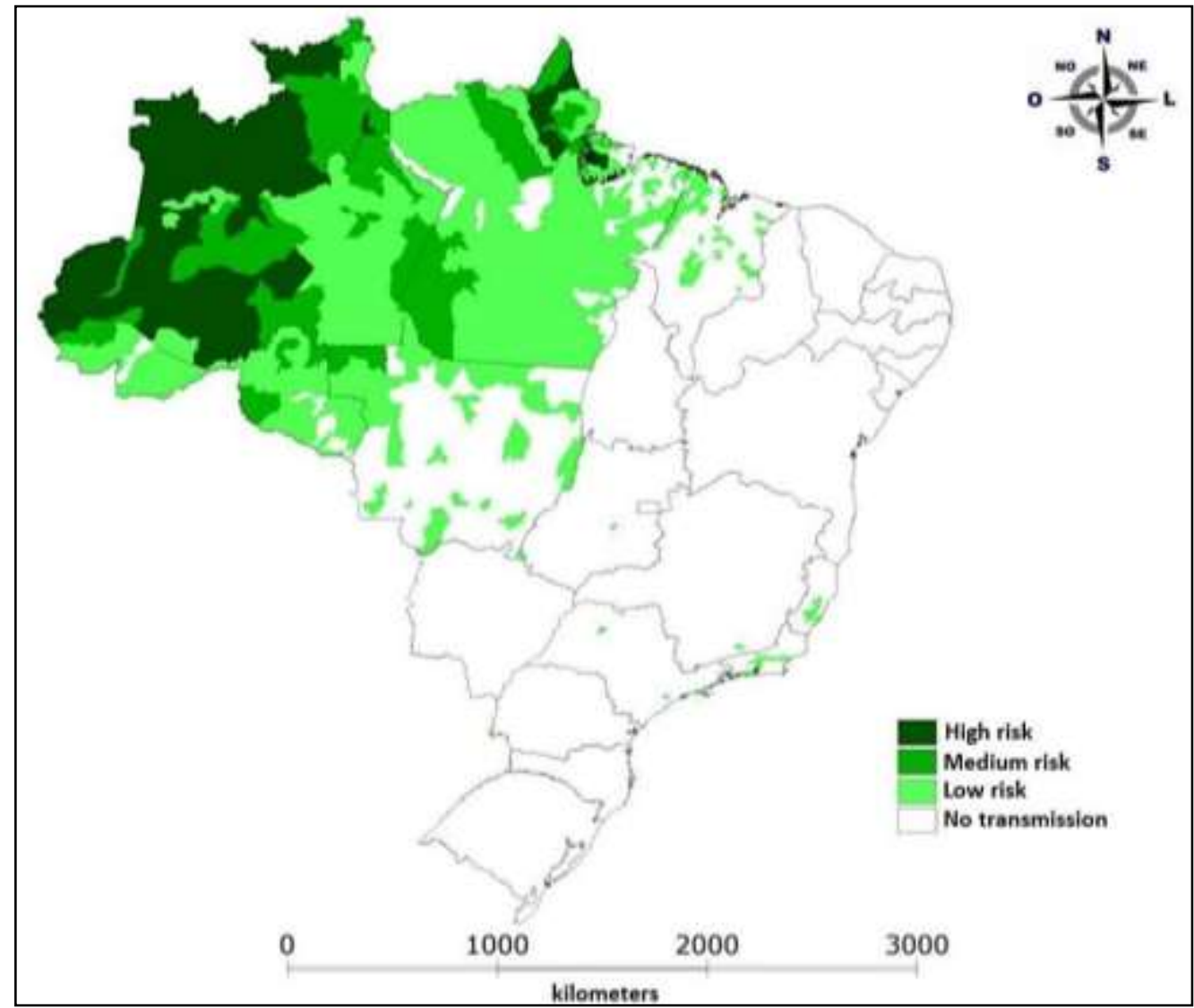

Source: Adapted from Sivep-Malária/SVS/MS, 2015 (52).

The Annual Parasitic Index is a risk marker for malaria transmission calculated from the number of positive malaria examinations in 1000 inhabitants within a given geographic space and period of time. Such classification is expressed in level of risk: low (0.1 to 9.9 ) medium (10.0 to 49.9), and high risk (equal or higher than 50.0 ). In Figure 8, it is shown the parasitic index of malaria in the endemic areas in 2015. Despite malaria being concentrated in the Amazon region, the distribution of cases does not occur in a homogeneous way, being influenced by different epidemiologic determinants (53). The states of Acre and Amazonas were responsible for approximately $70 \%$ of every case recorded in 2014 (51), and only three cities in the 
North region, Cruzeiro do Sul (Acre), Manaus (Amazonas), and Porto Velho (Rondônia), contributed with $22 \%$ of the cases recorded during that period (54).

Along the last decade, the country has recorded an important reduction in the amount of malaria cases each year mainly after 2006. According to the Ministry of Health, the amount of cases recorded in 2014 was the lowest in the last 35 years, and such average between 100 thousand to 150 thousand notified cases has been kept in the last 3 years (Figure 9). However, despite the advancements, it is worth to remember that over 20 million people are exposed to both $P$. falciparum and $P$. vivax which still contribute to a significant number of death. (51). Therefore, malaria continues to be an important public health issue in the country with a significant impact on the economic development of this region.

Figure 9 - Malaria reported cases per year, 2003-2017.

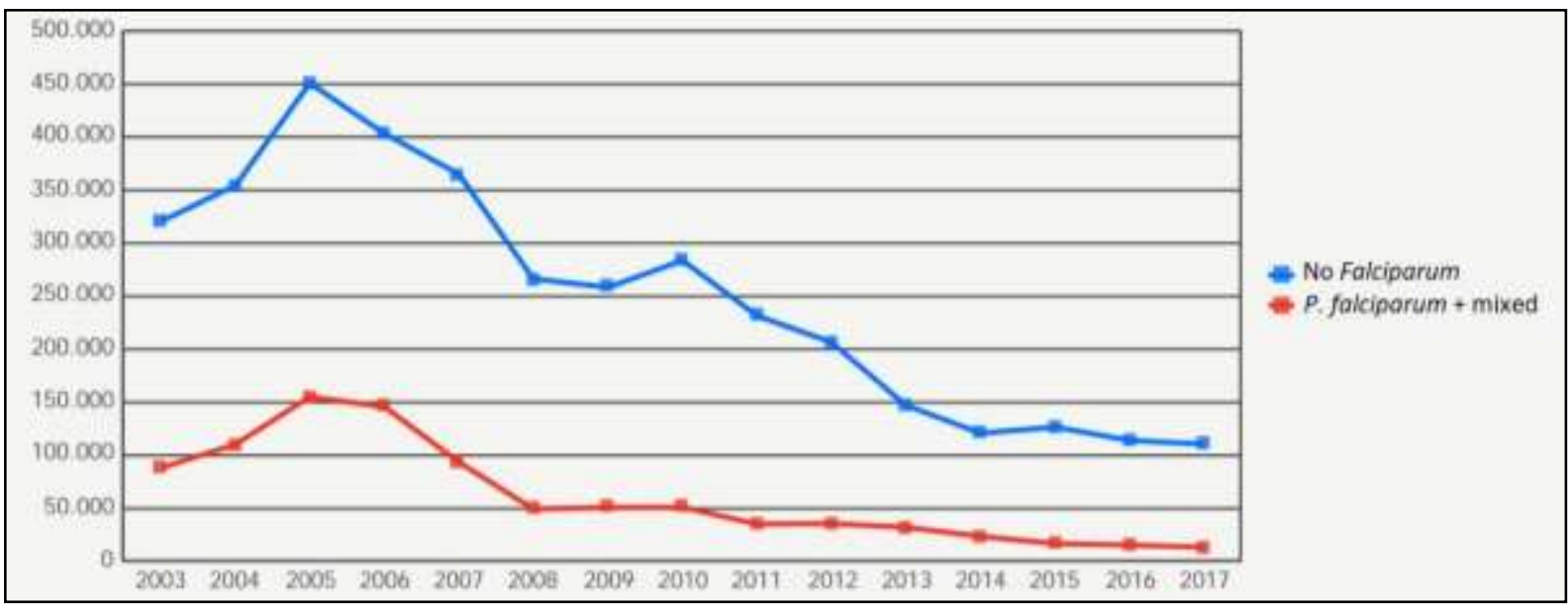

Source: Adapted from Sivep-Malária/SVS/MS, 2017 (55).

\subsubsection{Malaria in Acre and Juruá Valley Region}

As it can be observed in Figure 8, the state of Acre is endemic for malaria, concentrating areas of high risk of disease transmission, being one of the states of the Amazon region responsible for the highest amount of malaria cases in Brazil. According to the last epidemiological report, the state has notified more than 31 thousand autochthonous malaria cases, corresponding to $22 \%$ of the total cases recorded in the country in 2014 (51). Despite the whole state being endemic for the disease, most of malaria cases occur in the extreme west, in the region of the Alto Juruá Valley (Figure 10). 
Figure 10 - Distribution map of malaria transmission risk areas in Acre state in 2014.

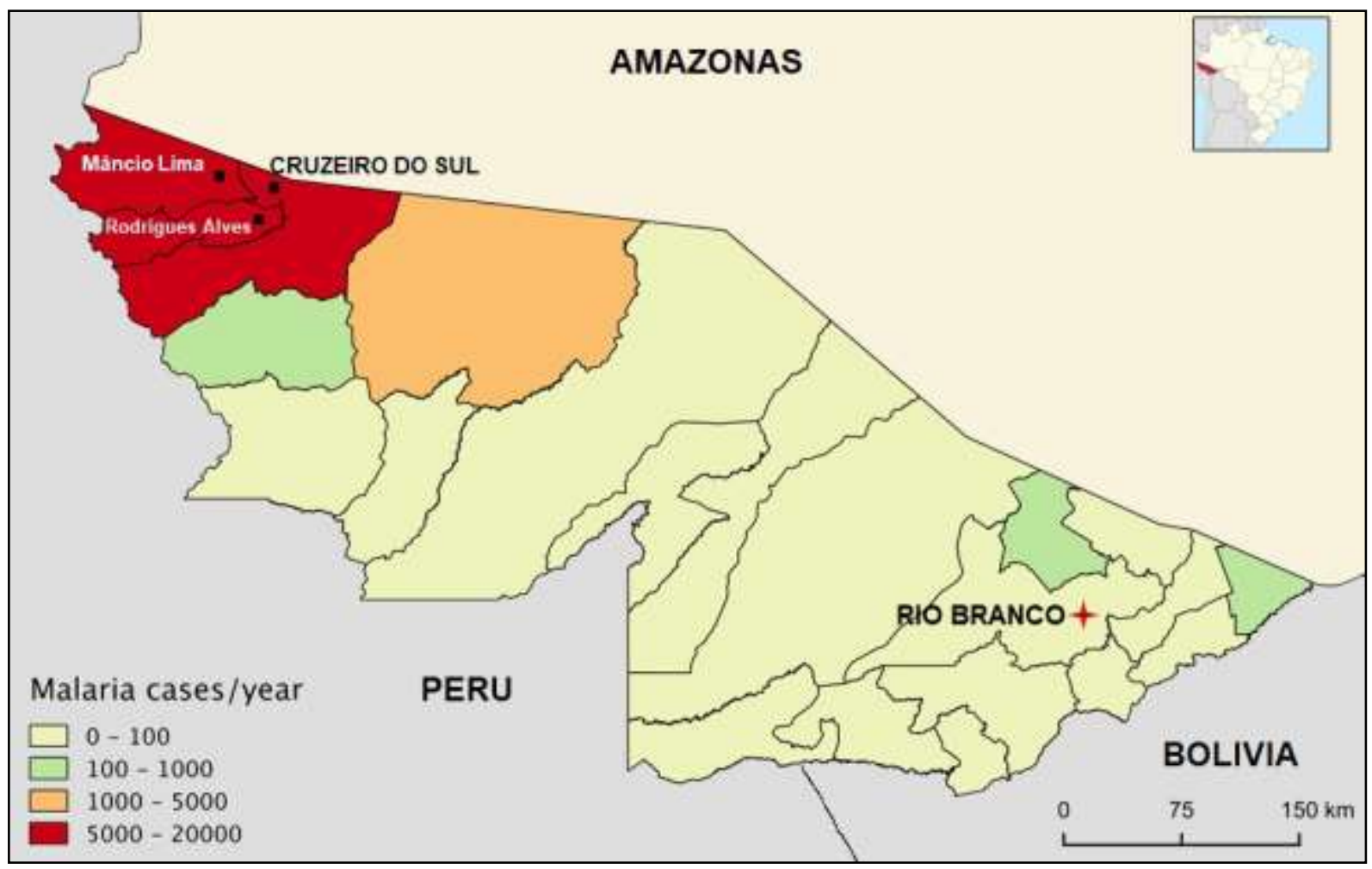

Source: Adapted from Sivep-Malária/SVS/MS (56).

The most prevailing species in the state, as well as in other states of the Amazon region is $P$. vivax. Despite the important reduction of cases caused by $P$. falciparum in the whole country, Acre state contributed with the highest amount of cases in 2014, 42\% from the total notified. Added to this, in 2013 and 2014, it was the State with the highest percentage of malaria falciparum cases (30\%) (Figure 11) (51). 
Figure 11 - Native cases of $P$. falciparum malaria and proportion of $P$. falciparum in relation to the total number of malaria cases in each Federal Unit, Amazon Region, 2013 and 2014.

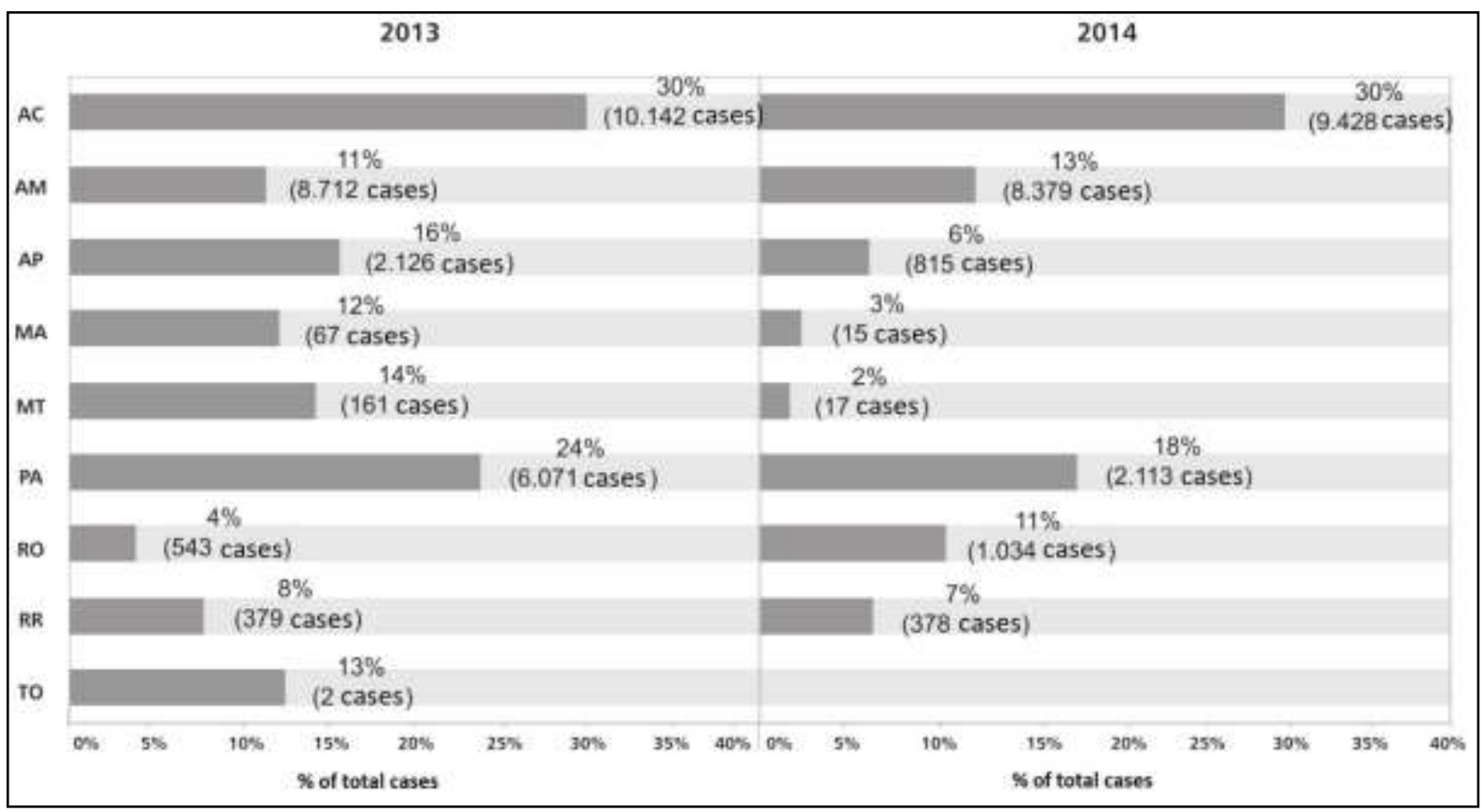

Source: Adapted from Sivep-Malária/SVS/MS (51).

The Alto Juruá Valley region is formed by the cities of Cruzeiro do Sul, Mâncio Lima, Rodrigues Alves, Porto Walter, and Marechal Thaumaturgo, and it is considered the region with the highest endemicity for malaria in the State. Among those cities, only Cruzeiro do Sul, Mâncio Lima and Rodrigues Alves were responsible for $91.8 \%$ of every malaria case notified in Acre state in 2014 , a profile that remained during the following years (56).

In 2012 and 2013, those three cities, Cruzeiro do Sul, Mâncio Lima and Rodrigues Alves detained one of the highest annual parasitic index in the Legal Brazilian Amazon (Figure 12). In 2016, the progress to reduce the amount of cases was not significant, and this can be observed by the high parasitic index that stayed similar in Cruzeiro do Sul, Mâncio Lima and Rodrigues Alves (231.9, 436.4, and 343.4 , respectively) (57), thus characterizing them as hyperendemic areas, with high risk of disease transmission (Figure 10). 
Figure 12 - Cases of malaria and Annual Parasitic Index by municipality in the Juruá Valley, 2012-2013.

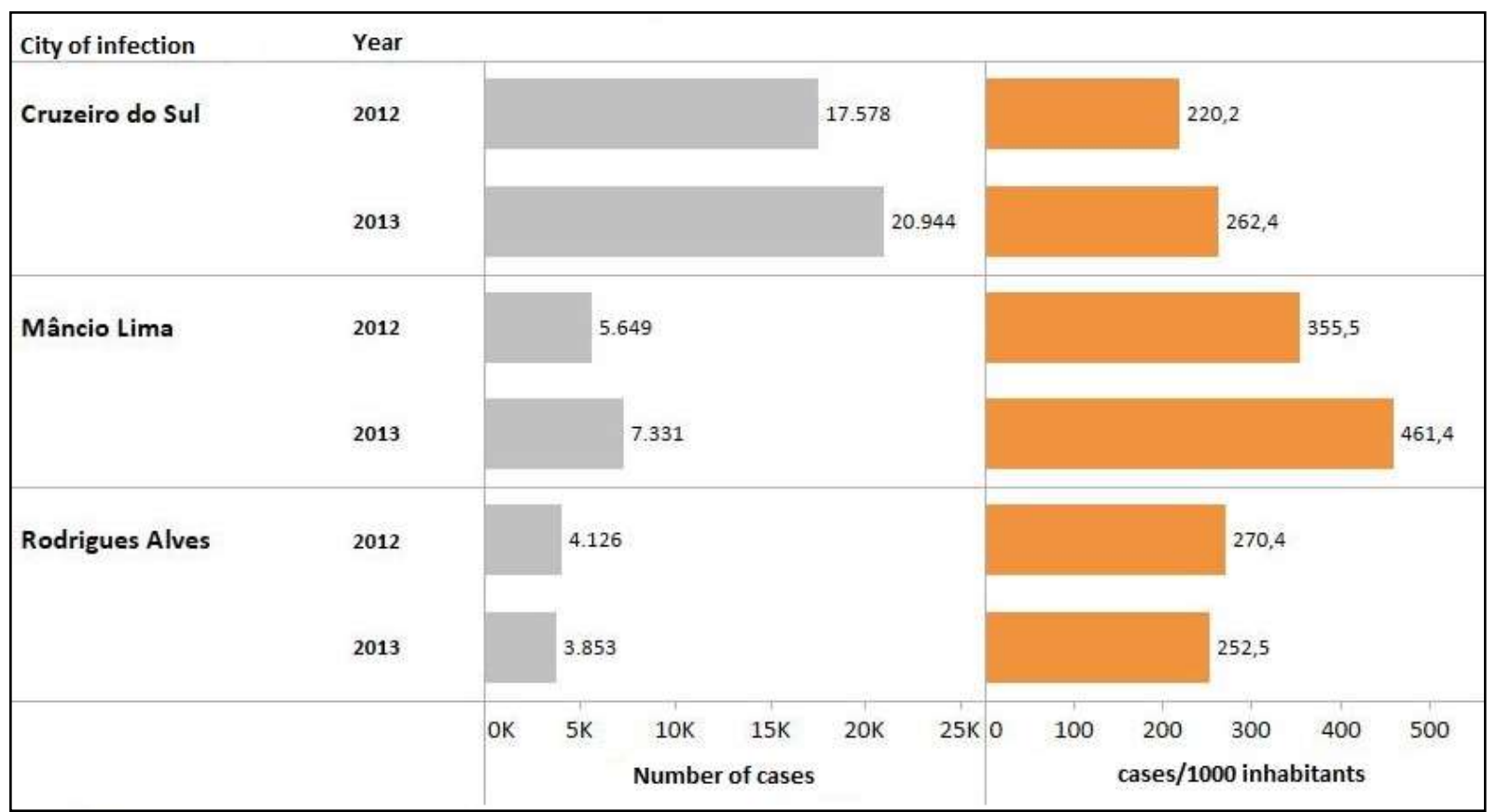

Source: Adapted from Sivep-Malária/SVS/MS (56).

\subsection{Malaria during pregnancy}

\subsubsection{Epidemiology of the gestational malaria}

Gestational malaria or malaria associated to pregnancy is defined as the presence of Plasmodium parasites in the peripheral blood or in the placenta, whether with or without clinical symptoms (58). It is estimated that each year, approximately 125 million women living in endemic countries for malaria get pregnant, and consequently, they face an increasing risk of developing malaria and its complications (Figure 13) (59). Such complications include severe anemia and maternal death, besides of increasing the risk for miscarriages, perinatal mortality, LBW as consequence of the prematurity and IUGR (60).

Of all pregnancies at risk of developing malaria, in 2007, approximately 85 million occurred in areas where the disease is transmited by $P$. falciparum. Addittionally, during the same period, it was estimated that above 92 million pregnancies occurred in endemic areas for P. vivax (Figura 13) (59). Each year, malaria infection is responsible for more than 10,000 maternal deaths and 200,000 
infant deaths (61). Moreover, malaria during pregnancy increases the risk of miscarriages, LBW and neonatal deaths (62).

Figure 13 - Malaria risk map for $P$. falciparum and $P$. vivax and corresponding number of pregnancies in each continent in 2007.

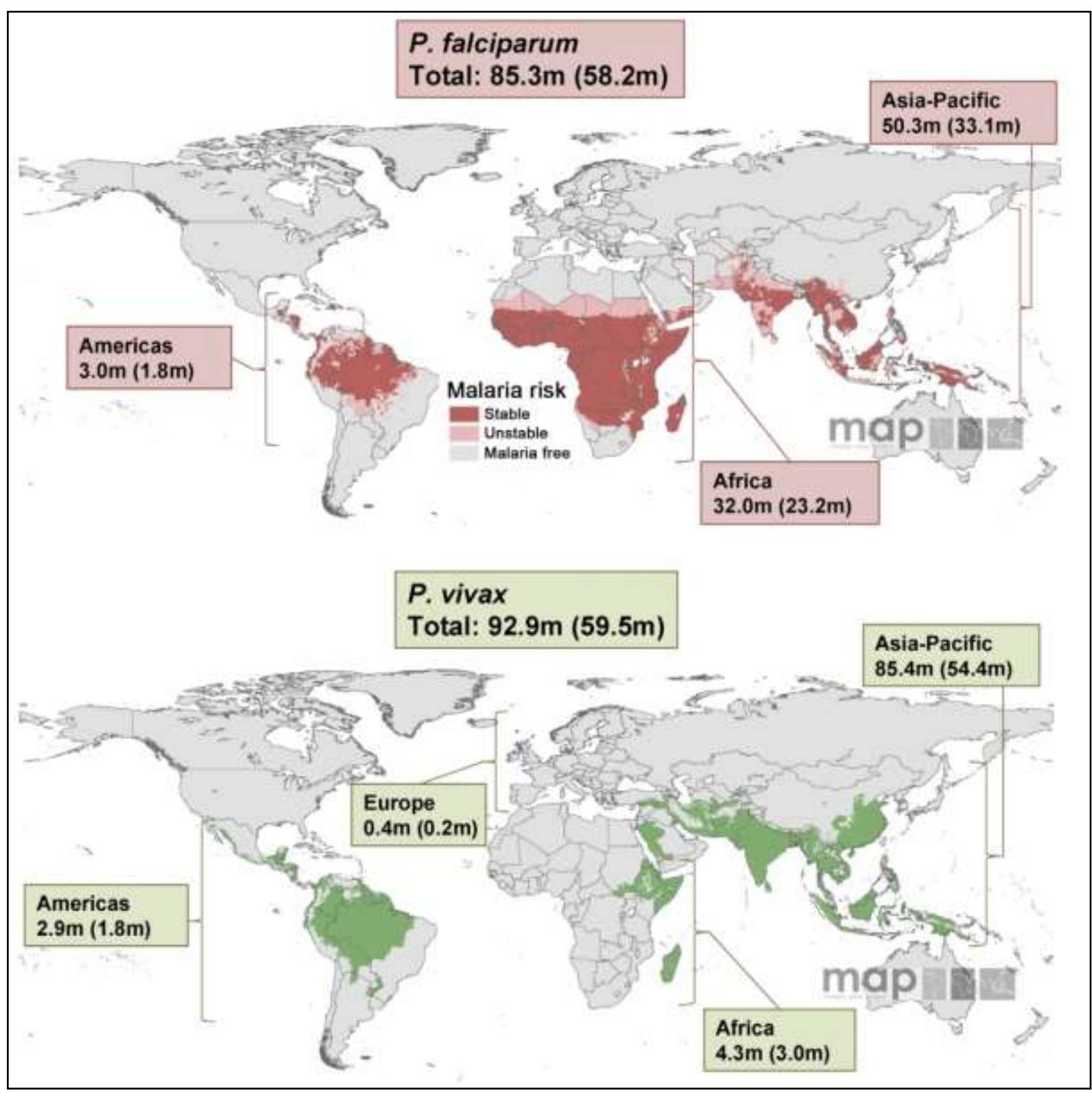

Source: Adapted from Dellicour S et al., 2010 (59).

Pregnant women living in hyperendemic areas and in areas with stable transmission are generally oligosymptomatic, where placental infections associated to anemia and LBW are frequent. Particularly, the most severe effects are observed in the first pregnancies, indicating the existence of a strong protective mechanism associated with specific immunity to placental forms of Plasmodium. Nevertheless, 
pregnant women living in hypoendemic areas and areas of unstable transmission present low previous immunity to malaria, with a high frequency of people having fever and other complications such as cerebral malaria, pulmonary edema, severe anemia, hypoglycemia, miscarriage, stillbirths, prematurity, LBW, congenital malaria, and even death $(50,63-65)$.

\subsubsection{Pathophysiology of gestational malaria}

Pregnant women are particularly more susceptible to malaria than nonpregnant women, and the reason for such vulnerability to infections has been the subject of an intense debate in the last few years. One of the main hypothesis has proposed that such susceptibility would be due to the physiological maternal immunomodulation caused by pregnancy that on one hand protects the fetus against the action of the maternal immunological system, but on the other hand, leaves the pregnant woman less resistant to infections (66). Actually, it is proposed that the susceptibility to gestational malaria occurs probably due to combined factors, such as alterations in the immunological and hormonal profiling associated to an accumulation of parasites in the placental tissue (67).

Hence, the physiopathology of the disease is determined by the fact that the placenta is one of the most important sites for parasite multiplication (68) and the accumulation of parasitic material takes place in the intervillous space (region where the maternal blood bathes the syncytiotrophoblast) $(69,70)$. Thus, the placenta provides a unique place for the development of subpopulations of the parasite, which binds to the receptors expressed by the syncytiotrophoblast, such as chondroitin sulfate A (CSA), present in large quantities in these cells (71). This facilitates the adhesion of infected erythrocytes mediated by a protein expressed in the membrane of these cells denominated PfEMP1 (Plasmodium falciparum erythrocyte membrane protein-1) (72-74). As a consequence, infected erythrocytes are sequestered and multiply in placental tissue, possibly preventing its later destruction by the spleen.

As such, placental malaria involves the presence of parasites in the intervillous space, and this can result in the accumulation of mononucllear cells, predominantly monocytes/macrophages inside this organ $(75,76)$. This results in the production of pro-inflammatory cytokines, as well as chemokines such as macrophage inflammatory proteins-1 (MIP-1) alpha (CCL3), monocyte chemoattractant protein-1 
(MCP-1; CCL2), and I-309 (CCL1), IL-8 (CXCL8). This molecular clews promote the recruitment of additional monocytes $(75,76)$, to formation of fibrin deposits (8) that impair maternal-fetal exchanges, resulting in adverse effects such as miscarriages, IUGR, premature births and LBW (74).

Specific immunity against the placental forms of the parasite is acquired after successive pregnancies, and this can prevent its sequestration in the placenta, thus avoiding the cascade of inflammatory events that lead to the adverse outcomes caused by the worsening of the disease (77). It is worth to point out that the most severe effects of malaria are generally observed in the first and second pregnancies, indicating the existence of a strong protection mechanism associated to a specific immunity achieved against Plasmodium placental forms (65). In those women, an increase in the parasitemia levels during pregnancy is an important marker of disease susceptibility.

\subsubsection{Diagnosis and treatment of the gestational malaria}

In Brazil, malaria diagnosis, regardless whether the individual is pregnant or not, it is generally performed through the microscopic examination of one's blood, which can be performed using thin and thick smears, collected by digital puncture. In despite of that, presently there are alternative methods of diagnose that use more sensitive technologies, this method is considered the golden standard, mainly due to its low cost, being easy to be implemented in areas of difficult access and for being effective to detect and quantify the parasite (42). In relation to placental malaria, the histologic examination of the placenta at the moment of birth is the standard diagnosis, but it requires qualified professionals, which it is of high cost and difficult to be available (78).

In particular for pregnant women that live in the states of the Amazon region, the National Malaria Control Program published the Joint Informative Note no. $002 / 2014$, where it was introduced the thick smears examination done in every antenatal care and at the moment of delivery (79). This initiative ensures that pregnant women have a greater access to clinical examination, thus enabling the early diagnosis and further treatment, which will lead to a better follow-up, guaranteeing that they perform the recommended therapeutic schedule (79). 
The Ministry of Health has several strategies to control and combat malaria during pregnancy, and drug treatment is considered one of the major methods adopted. The therapeutic regimens are organized in official protocols, and the use ranges according to parasite species, age and/or woman's weight, disease severity and gestational age (80).

In short, for a non-complicated malaria infection in pregnant women promoted by $P$. vivax, it is recommended the usage of chloroquine as first chosen drug in a three-day treatment schedule. In addition, it is important to use a weekly schedule of chloroquine for relapse prevention. For infections with $P$. falciparum, along the whole gestational period, but especially along the first trimester, it is advocated the use of an association of quinine for seven days and clindamycin for five days. An alternative schedule to treat infections with $P$. falciparum that is recommended only for the second and third gestational trimesters assumes a fixed combination of artemerther and lumefantrine in a three-day schedule (80). It is worth to point out that in Brazil, the prophylaxis through the intermittent preventive treatment with regular doses of sulfadoxine and pyrimethamine is not used.

It is highly recommended, regardless the type of parasite or gestational period that pregnant women undergo a rigorous medical assessment after diagnosis in order to get the correct indication of the therapeutic schedule to be used and for the complete assessment of the risks that the infection can bring both to the mother and the fetus. Furthermore, despite of the proved safety of using those drugs during pregnancy, the risks are not yet completely set, and using them in an inappropriate way can lead to parasitic resistance (80).

\subsubsection{Consequences of gestational malaria and the risk for growth restriction and low birth weight}

Much of the information regarding gestational malaria consequences came from studies done with the $P$. falciparum species, performed in African countries. Despite the great advances in research on gestational malaria in Latin America, more studies are needed to consolidate knowledge, mainly regarding $P$. vivax, which is considered the most prevailing species in the region $(81,82)$.

Infection by $P$. falciparum during pregnancy has been recognized as an important determinant for LBW, which is normally more accentuated in primigravida 
$(13,83)$ that might reach the second and third pregnancies in low transmission areas (84). Similar adverse effects have been reported in $P$. vivax infections, although the decrease in birth weight and anemia are less severe when compared to infections caused by $P$. falciparum (13). In endemic regions, the association of malaria with complications such as prematurity (8-36\%), IUGR (13-70\%), LBW (8-14\%) and child mortality (3-8\%) is frequent (85).

Anemia is a classic consequence of malnutrition, but it is also one of the most frequent complications of gestational malaria and an important cause of maternal death in endemic areas, besides of being an independent risk factor both for LBW and IUGR (Figure 14) (86). Anemia can cause reduction in the oxygen transportation to the fetus due to the destruction of erythrocytes promoted by the parasite, suppression of hematopoiesis, and also by the immunological response to infection $(80,87-89)$. In high transmission areas for malaria, around $25 \%$ of the population presents severe anemia (hemoglobin $<7 \mathrm{~g} / \mathrm{dl}$ ) (90).

Miscarriages and stillbirths are other two important consequences observed in pregnant women with malaria. These complications can occur due to several factors, but mainly by placental infection generating an intense inflammatory response that decreases the amount of oxygen and nutrients taken by the fetus, and by the hyperpyrexia, that stimulates the prostaglandins production, which exerts an excitatory action on the uterine muscle resulting in miscarriage $(50,91,92)$.

The growth restriction and low birth weight were clearly associated to the sequestration of infected erythrocytes and hemozoin (malarial pigment) accumulation in the placenta $(75,93)$. This can be associated, for instance, to alterations in the nutrient transportation function (Figure 14). Supposedly, the high density of parasites, chronic parasitic infection in placental blood and its association with the immune response can lead to the presence of intervillositis and to glucose and oxygen consumption, which should primarily be provided to the fetus (87). Thickening of the basal membrane of syncytiotrophoblast has also been observed in histopathological studies of infected placentas that can interfere in nutrients transportation to the fetus (94). Nevertheless, the details of those biological processes remain unclear, mainly due to the restrict access to the placenta at term collected only after birth (87).

Besides the mononuclear cell infiltrate and fibrin deposits, placental malaria is associated with several other alterations inside the organ, including thickening of the syncytiotrophoblast basal membrane, increase in the amount of syncytial nuclear 
aggregates and fibrinoid necrosis (94). Recently, a study suggested that such changes can affect the functional integrity of the placenta by reducing both nutrients transportation and its secretory functions, probably being more noxious for fetal growth in the third trimester of pregnancy, when the demands for nutrients and gases are more intense (8).

Several mechanisms in gestational malaria are known to be associated to IUGR and LBW (Figure 14). In some studies, it was also proposed that the dysregulation of molecular mechanisms associated to the angiogenic processes, such as the angiopoietins (ANG-1, ANG-2), vascular endothelial growth factor (VEGF) and its soluble receptor (sVEGFR1 or sFlt-1), which inhibit the trophoblastic invasion. This dysregulation also affects the remodeling of the spiral uterine arteries, which have been associated to the occurrence of IUGR and low weight of the newborns from pregnant women presenting malaria during gestation $(89,95-97)$.

Limited studies even suggest that placental malaria can alter both the maternal and fetal secretion of hormones that regulate fetal growth $(98,99)$. The main changes include decreased production of growth factors similar to the insulin (IGFs) and leptin, which is a peptide hormone that influences the homeostasis and regulates the neuroendocrine function. Leptin is produced in significant amounts by the syncytiotrophoblast in more advanced stages of pregnancy, and in several studies, decrease in its levels have been associated to fetal growth restriction $(7,97,100)$. 
Figure 14 - Possible pathways to malaria-induced intrauterine growth restriction.

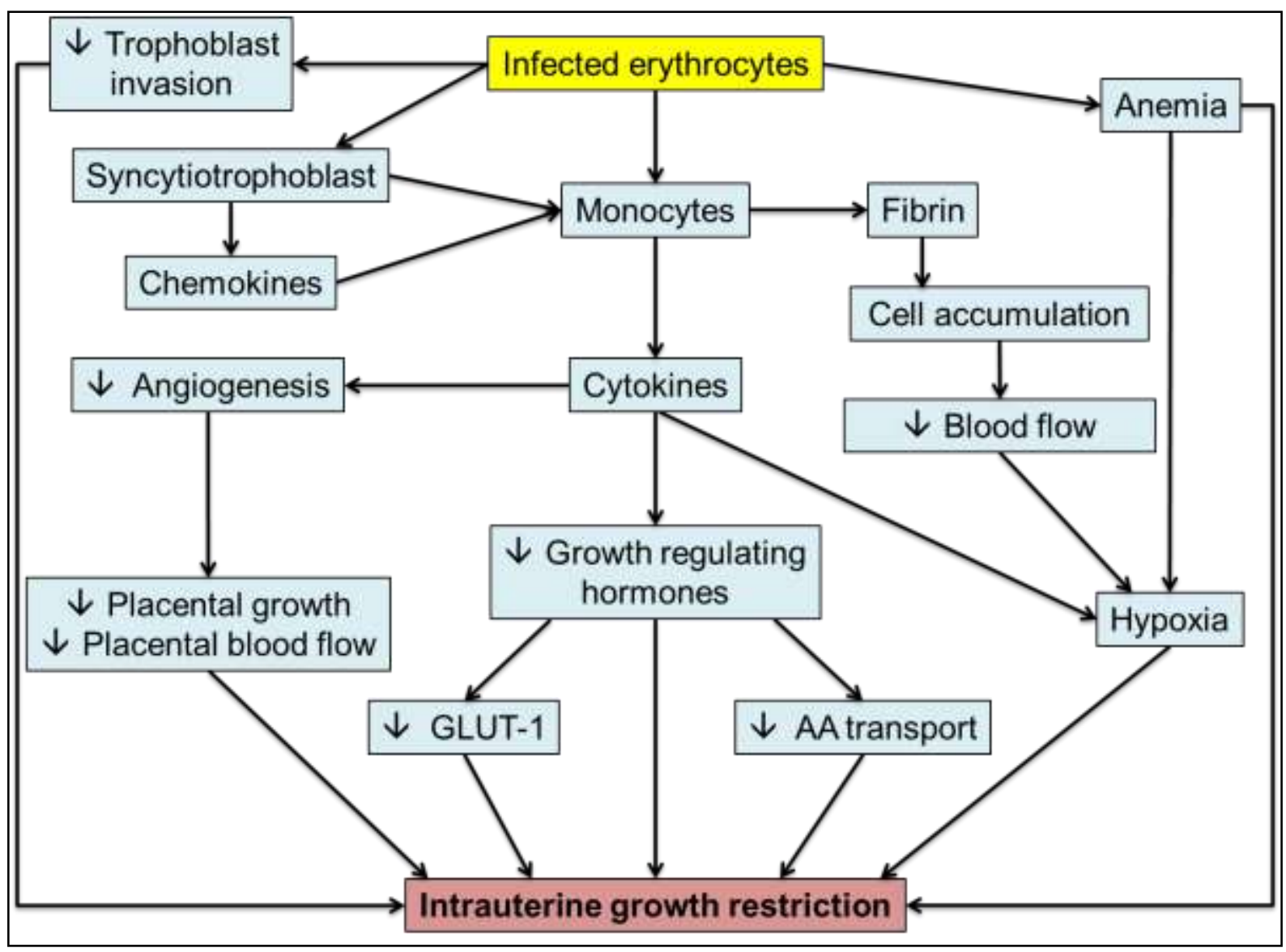

The sequestration and/or accumulation of infected erythrocytes in the placenta can activate monocytes and other cells that cause changes in placental function. Placental malaria induces the production of chemoattractant secretions by the syncytiotrophoblast and the accumulation of cytokine-secreting monocyte in the intervillous space. This inflammation can alter the levels of fetal growth hormones or directly decrease the activity of placental nutrient transporters. Cytokines could directly or indirectly affect nutrient transport mechanisms. Cytokines and cell accumulation can lead to placental hypoxia. Malaria is associated with maternal anemia, which can directly cause IUGR. Infection in early pregnancy might hinder trophoblast invasion and can impair vascular development. Monocytes in the intervillous space can also disrupt placental blood flow by inhibiting angiogenesis. IUGR could therefore result from changes in placental blood flow, vascular development and/or nutrient transport activity, or from hormonal changes operating in the maternal or fetal circulations. GLUT1=glucose transporter 1; $A A=$ amino acids. Source: Adapted from $(8,67)$.

Placental malaria also influences the hormone of placental growth (hPGH) and the human placental lactogen (hPL), which have a central role in the maternal adaptation to pregnancy. Fetal weight in the second half and in the end of gestation is directly correlated with $\mathrm{hPL}$ and $\mathrm{hPGH}$ concentrations both in the maternal and fetal plasma (20), and in pregnancies complicated by fetal growth restriction, it is detected a decrease in the concentration of those hormones (101). Added to that, it was observed that the pro-inflammatory cytokines are consistently high in placentas 
infected with Plasmodium, especially those with a chronic inflammation (67), which may potentially result in adverse effects to the fetus.

Finally, in an interesting way, recent studies have shown that fetal growth and survival are also influenced by the gender of the fetus. In average, male babies born larger than female babies, although female babies have higher survival rates, particularly among the newborns with LBW and extreme LBW $(102,103)$. Under adverse conditions, as for instance in a Plasmodium infection, each gender seems to adopt a different growth strategy: males tend to continue growing, while females have their growth restricted. This is probably due to the way they handle stress along pregnancy. It is possible that such difference is mediated by the placenta and provided by the specificities of each gender in the expression and regulation of placental genes, proteins, steroids, and placental structure, mainly concerning vasculature (103). In two studies examining the interaction between fetal gender and response to malaria, it was evidenced that the maternal infection was associated to a decrease in the average birth weight mainly in newborn females (104).

\subsection{Health information systems}

The main role of the information systems is to promote the acquisition of knowledge, which should support the management of health services. Brazil is a country with a wide list of health information systems available for different planning purposes, management, assessment, social control, teaching, and research (105). Among every database available and within the context of this work, two important information systems must be pointed out: the Information System of Live Births (SINASC) and the Epidemiological Surveillance for Malaria (SIVEP-Malaria).

\subsubsection{Live Birth Information System}

Implemented in 1990 by the Ministry of Health, SINASC was assembled with the purpose of improve the information quality by collecting and producing information on the occurrence of births, maternal data, pregnancy, delivery and newborn data under the responsibility of the State and Municipal Health Secretariats $(23,106)$. This system can be used to get health, demographic, and epidemiological markers related to the management commitments of the cities, and for the planning 
and management of health services by means of the elaboration of frequency reports of events and cross between variables (107-109).

The system represents an important source of information for research and assessment in area of health linked to the maternal-child cares (110), as it has unique characteristics that few countries have, such as the national coverage, and a computerized system on transmission data (111). Furthermore, it is an important source to calculate the proportion of live births with LBW, mothers with four or more prenatal consultations, types and places of birth, presence of congenital diseases, added to other characteristics (106).

SINASC is supplied through information contained in the Certificate of Live Birth (DNV), which is a pre-numbered document standardized by the Ministry of Health jointly presented in three copies. The issuance of DNV is the responsibility of health professionals or midwives (duly recognized and linked to the health units) responsible by assisting the birth or the newborn (112). All the routing workflow, filling protocol, and information processing are defined by the Ministry of Health, and they are available in instruction and procedure manuals $(112,113)$.

\subsubsection{Epidemiological Surveillance System - Malaria}

Malaria is a mandatory notification disease, and hence, all the suspected or confirmed cases must be mandatorily notified to the health authorities. In 2003, the National Malaria Control Program implemented the Epidemiological Surveillance for Malaria (SIVEP-Malaria) in every state of the Amazon region aiming to improve the information flow and quality, integrating the cities, states and the Union (114). SIVEPMalaria is a present and important notification system of malaria cases of the Ministry of Health, whose data is provided through the fulfillment of a notification and investigation sheet at the disease diagnosis units both in the public and private systems of health (115).

The notification sheet of the disease is organized in blocks, and it includes general information of the patient such as gender, age, whether pregnant or not, information on the probable site of infection, data from the examination including species of parasite and parasitemia quantification. It also provides information on the treatment used (116). 
Such important system of the Ministry of Health collects and provides updated information on disease incidence and distribution of cases in the Amazon region. Thus, it is considered an important tool for the analysis of the case's oscillations in different regions and contexts enabling to set effective strategies for controlling actions and malaria prevention (117). Furthermore, it is possible to determine which are the areas or population groups more affected by the disease, thus enabling to direct resources for worst affected regions, intensifying the fight against the disease (118). 


\section{FINAL CONSIDERATIONS}

1. When analyzing the databases quality, it is of extreme importance to identify the period in which the evaluations occurred. The years of 2005 and 2010 were chosen for the study entitled "Effectiveness of the live births information system in the far-western Brazilian Amazon" with the objective of verifying the information systems accuracy in a year of stability and prospection (2005) and a year of transaction (2010) in which the newborns' declaration (Declaração de Nascidos Vivos, DNV) has been substituted by a new model. This allow us to observe that even with a reduced coverage and an incomplete registration of the studied variables collected in 2010, SINASC is one of the most important, complete and reliable systems of information working for the Ministry of Health.

2. The challenge of linkage databases was to overcome the reduced number of common variables between both information systems. The existence of two complete sets of variables from SINASC and SIVEP-Malaria allowed the complition of the study "Malaria during pregnancy and newborns outcome in an unstable transmission area in Brazil: a population-based record linkage study". Conclusions drawn from the aforementioned research were of extreme importance for the assessment of malaria impact during gestation relying on data collected over 9 years. It is worth to highlight that even with infection premature diagnosis and treatment administration within 48 hours, it was possible to observe severe deleterious effects such as low birth weight and prematurity among children born from women with malaria in pregnancy.

3. The great majority of studies that tried to evaluate the effects of malaria in pregnancy presented almost exclusively the impact of infection in newborns' birth weight, together with prematurity and stillbirths. Having this in consideration, with the study "Plasmodium falciparum infection during pregnancy impairs fetal head growth: prospective and populational-based retrospective studies" we have managed to show that $P$. falciparum infections may also impair the proper development of other fetal/newborn's 
anthropometric characteristics, especially normal head circumference. Additionally, $P$. falciparum infections were also shown to be associated to some microcephaly cases. As such, these findings reinforce the importance of evaluating placental infection promoted by the parasite and its consequences on fetal growth and development as a whole. 


\section{REFERENCES*}

1. Sadler TW. Langman Embriologia Médica. 13 ed. Rio de Janeiro: GuanabaraKoogan; 2016. 350 p.

2. Montenegro CAB, Rezende Filho J. Obstetrícia Fundamental. 13 ed. Rio de Janeiro: Guanabara-Koogan; 2014. 766 p.

3. Hill MA. Embryology Human Carnegie stage 1-23.jpg [Internet]. 2017 [cited 2017 Sep 20]. Available from:

https://embryology.med.unsw.edu.au/embryology/index.php/File:Human_Carne gie_stage_1-23.jpg

4. The McGraw-Hill Companies. Embryonic germ layer [Internet]. 2016 [cited 2016 Sep 20]. Available from:

http://academic.emporia.edu/sievertg/lectures/develop.htm

5. Moore KL, Persaud T. The Developing Human: Clinically Oriented Embryology. 5 ed. Philadelphia: WB Saunders Company; 1993. 493 p.

6. Montanari T. Embriologia: texto, atlas e roteiro de aulas práticas. 1 ed. Porto Alegre: Ed. do autor; 2013. 199 p.

7. Mullis P-E, Tonella P. Regulation of fetal growth: consequences and impact of being born small. Best Pract Res Clin Endocrinol Metab [Internet]. 2008 Feb [cited 2012 Mar 26];22(1):173-90. Available from: http://www.ncbi.nlm.nih.gov/pubmed/18279787

8. Umbers AJ, Aitken EH, Rogerson SJ. Malaria in pregnancy: small babies, big problem. Trends Parasitol [Internet]. 2011 Apr [cited 2011 Jul 8];27(4):168-75. Available from: http://www.ncbi.nlm.nih.gov/pubmed/21377424

9. Burton GJ, Fowden a L. Review: The placenta and developmental programming: balancing fetal nutrient demands with maternal resource allocation. Placenta [Internet]. 2012 Feb [cited 2012 Apr 17];33 Suppl:S23-7. Available from: http://www.ncbi.nlm.nih.gov/pubmed/22154688

10. Mussi-Pinhata MM, Bissani C. Recém-nascido de baixo peso. Pediatrics. 1994;7(16):1-12.

11. Gude NM, Roberts CT, Kalionis B, King RG. Growth and function of the normal human placenta. Thromb Res [Internet]. 2004 Jan [cited 2012 Mar 22];114(56):397-407. Available from: http://www.ncbi.nlm.nih.gov/pubmed/15507270

12. Montenegro CAB, Rezende Filho J. Obstetrícia fundamental. 12 ed. Rio de Janeiro: Guanabara-Koogan; 2011. 740 p.

*De acordo com:

International Committee of Medical Journal Editors. [Internet]. Uniform requirements for manuscripts submitted to biomedical journals. [2011 Jul 15]. Available from: http://www.nlm.nih.gov/bsd/uniform_requirements.htlm 
13. McGready R, Davison BB, Stepniewska K, Cho T, Shee H, Brockman A, et al. The effects of Plasmodium falciparum and $P$. vivax infections on placental histopathology in an area of low malaria transmission. Am J Trop Med Hyg [Internet]. 2004 Apr;70(4):398-407. Available from:

http://www.ncbi.nlm.nih.gov/pubmed/15100454

14. Benirschke K, Kaufmann P. Pathology of the human placenta. 4 ed. New York: Springer; 2000. 950 p.

15. Langheinrich a C, Vorman S, Seidenstücker J, Kampschulte M, Bohle RM, Wienhard J, et al. Quantitative 3D micro-CT imaging of the human fetoplacental vasculature in intrauterine growth restriction. Placenta [Internet]. 2008 Nov [cited 2012 Apr 21];29(11):937-41. Available from:

http://www.ncbi.nlm.nih.gov/pubmed/18851884

16. Jansson T, Powell TL. IFPA 2005 Award in Placentology Lecture. Human placental transport in altered fetal growth: does the placenta function as a nutrient sensor? - a review. Placenta [Internet]. 2006 Apr [cited 2012 May 10];27 Suppl A:S91-7. Available from: http://www.ncbi.nlm.nih.gov/pubmed/16442615

17. Lewis RM, Poore KR, Godfrey KM. The role of the placenta in the developmental origins of health and disease-Implications for practice. Rev Gynaecol Perinat Pract [Internet]. 2006 Jun [cited 2012 Apr 19];6(1-2):70-9. Available from: http://linkinghub.elsevier.com/retrieve/pii/S1871232005001033

18. Salafia CM, Adrian K, Maas EM. Placenta and Fetal Growth Restriction. 2006;49(2):236-56.

19. Vedmedovska N, Rezeberga D, Teibe U, Melderis I, Donders GGG, SALAFIA CM. Placental pathology in fetal growth restriction. Eur J Obstet Gynecol Reprod Biol [Internet]. 2010 Mar [cited 2012 Jun 18];155(1):36-40. Available from: http://www.ncbi.nlm.nih.gov/pubmed/21183268

20. Moreira Neto AR et al. Etiologia da restrição de crescimento intrauterino (RCIU). Com. Ciências Saúde. 2011;22 Suppl 1:S21-S30.

21. Lewis RM, Cleal JK, Hanson M a. Review: Placenta, evolution and lifelong health. Placenta [Internet]. 2012 Feb [cited 2012 Apr 7];33 Suppl:S28-32. Available from: http://www.ncbi.nlm.nih.gov/pubmed/22205051

22. Uchimura TT, Pelissari DM. Baixo peso ao nascer e fatores associados. Rev Gaúcha Enferm [Internet]. 2008 [cited 2012 Mar 2];29(1):33. Available from: http://seer.ufrgs.br/index.php/RevistaGauchadeEnfermagem/article/viewArticle/ 5261

23. World Health Organization. Optimal feeding of low birth-weight infants in lowand middle-income countries 2011. Geneva: World Health Organization; 2011. $51 \mathrm{p}$.

24. Monteiro CA, Benicio M, Ortiz LP. Tendência secular do peso ao nascer na cidade de São Paulo (1976-1998). Rev Saude Publica [Internet]. 2000 [cited 2012 Mar 2];34(6 Supl):26-40. Available from: http://www.scielosp.org/pdf/rsp/v34n6s0/3516.pdf

25. United Nations Children's Fund and World Health Organization. Low 
Birthweight: Country, regional and global estimates. New York: United Nations Children's Fund; 2004. 27 p.

26. Lubchenco LO, Hansman C, Dressler M, Boyd E. Intrauterine growth as estimated from liveborn birth-weight data at 24 to 42 weeks of gestation. Pediatrics [Internet]. 1963 Nov [cited 2012 Feb 9];32(5):793-800. Available from: http://www.ncbi.nlm.nih.gov/pubmed/14075621

27. Acog. ACOG practice bulletin: Intrauterine growth restriction. Int J Gynecol Obstet [Internet]. 2001;72:85-96. Available from: http://www.ncbi.nlm.nih.gov/pubmed/21664690

28. Aucott SW, Donohue PK, Northington FJ. Increased morbidity in severe early intrauterine growth restriction. J Perinatol Off J Calif Perinat Assoc [Internet]. 2004;24(7):435-40. Available from:

http://www.ncbi.nlm.nih.gov/entrez/query.fcgi?cmd=Retrieve\&db=PubMed\&dop $\mathrm{t}=$ Citation\&list_uids $=15116139$

29. Kaijser M, Edstedt Bonamy A-K, Akre O, Cnattingius S, Granath F, Norman M, et al. Perinatal Risk Factors for Diabetes in Later Life. Diabetes [Internet]. 2009;58(3):523-6. Available from: http://diabetes.diabetesjournals.org/content/58/3/523.full.pdf

30. Maulik D, Frances Evans J, Ragolia L. Fetal growth restriction: pathogenic mechanisms. Clin Obstet Gynecol [Internet]. 2006;49(2):219-27. Available from: http://www.ncbi.nlm.nih.gov/pubmed/16721102

31. Pollack RN DM. Intrauterine growth retardation: definition, classification, and etiology. Clin Obs Gynecol. 1992;35(1):99-107.

32. Moore K a., Simpson J a., Thomas KH, Rijken MJ, White LJ, Lu Moo Dwell S, et al. Estimating Gestational Age in Late Presenters to Antenatal Care in a Resource-Limited Setting on the Thai-Myanmar Border. PLoS One [Internet]. 2015;10(6):e0131025. Available from:

http://dx.plos.org/10.1371/journal.pone.0131025

33. Karl S, Li Wai Suen CSN, Unger HW, Ome-Kaius M, Mola G, White L, et al. Preterm or Not - An Evaluation of Estimates of Gestational Age in a Cohort of Women from Rural Papua New Guinea. PLoS One [Internet]. 2015;10(5):e0124286. Available from: http://dx.plos.org/10.1371/journal.pone.0124286

34. Paul REL, Ariey F, Robert V. The evolutionary ecology of Plasmodium. Ecol Lett [Internet]. 2003 Sep;6(9):866-80. Available from: http://doi.wiley.com/10.1046/j.1461-0248.2003.00509.x

35. Lacerda MVG. Manifestações Clínicas e Patogênese da Plaquetopenia na Malária. [tese (Doutorado em Medicina Tropical)]. Brasília: Núcleo de Medicina Tropical, Universidade de Brasília; 2007.

36. TA TH, Hisam S, Lanza M, Jiram Al, Ismail N, Rubio JM. First case of a naturally acquired human infection with Plasmodium cynomolgi. Malaria Journal, v. 13, n. 1, p. 68-74, 2014. Available from: https://www.ncbi.nlm.nih.gov/pubmed/24564912

37. Cox-Singh J, Davis T, Lee K. Plasmodium knowlesi malaria in humans is 
widely distributed and potentially life threatening. Clin Infect [Internet]. 2008 [cited 2012 Mar 2];46(2):165-71. Available from:

http://cid.oxfordjournals.org/content/46/2/165.short

38. Pessoa SB, Martins AV. Parasitologia Médica. 11 ed. Rio de Janeiro: Guanabara-Koogan; 1988. 872 p.

39. Sturm A, Amino R, van de Sand C, Regen T, Retzlaff S, Rennenberg A, et al. Manipulation of host hepatocytes by the malaria parasite for delivery into liver sinusoids. [Internet]. Vol. 313, Science. 2006 Sep [cited 2011 Jul 22]. Available from: http://www.ncbi.nlm.nih.gov/pubmed/16888102

40. Moxon CA, Grau GE, Craig AG. Malaria: modification of the red blood cell and consequences in the human host. Br J Haematol [Internet]. 2011 May 28 [cited 2012 Feb 29];154:670-9. Available from:

http://www.ncbi.nlm.nih.gov/pubmed/21623767

41. White NJ, Pukrittayakamee S, Hien TT, Faiz MA, Mokuolu OA, Dondorp AM. Malaria. Lancet [Internet]. 2014 Feb;383(9918):723-35. Available from: http://linkinghub.elsevier.com/retrieve/pii/S0140673613600240

42. Brasil. Ministério da Saúde. Manual de Diagnóstico Laboratorial da Malária. 1 ed. Brasília: Ministério da Saúde; 2005. 112 p.

43. World Health Organization. Guidelines for the treatment of malaria. Geneva: World Health Organization; 2006. 253 p.

44. Kwiatkowski DP. How Malaria Has Affected the Human Genome and What Human Genetics Can Teach Us about Malaria. Am J Hum Genet [Internet]. 2005 Aug;77(2):171-92. Available from: http://linkinghub.elsevier.com/retrieve/pii/S0002929707629097

45. Marsh K, Kinyanjui S. Immune effector mechanisms in malaria. Parasite Immunol [Internet]. 2006 Jan;28(1-2):51-60. Available from: http://doi.wiley.com/10.1111/j.1365-3024.2006.00808.x

46. Guerra CA, Snow RW, Hay SI. Mapping the global extent of malaria in 2005. Trends Parasitol. 2006;22(8):353-8.

47. World Health Organization. World Malaria Report 2016 [Internet]. World Health Organization. Geneva: World Health Organization; 2016. 186 p. Available from: http://apps.who.int/iris/bitstream/10665/252038/1/9789241511711 eng.pdf?ua $=1$

48. Filler S. Malaria [Internet]. 2017 [cited 2017 Sep 20]. Available from: http://scottfiller.org/malaria/

49. Freedman DO, Weld LH, Kozarsky PE, Fisk T, Robins R, von Sonnenburg F, et al. Spectrum of Disease and Relation to Place of Exposure among III Returned Travelers. N Engl J Med [Internet]. 2006 Jan 12;354(2):119-30. Available from: http://www.nejm.org/doi/abs/10.1056/NEJMoa051331

50. McGregor IA. Epidemiology, malaria and pregnancy. Am J Trop Med Hyg [Internet]. 1984 Jul;33(4):517-25. Available from: http://www.ncbi.nlm.nih.gov/pubmed/6383091

51. Brasil. Ministério da Saúde. Secretaria de Vigilância em Saúde. Boletim 
Epidemiológico. Brasília: Ministério da Saúde; 2015;46:1-5.

52. Brasil. Ministério da Saúde. Secretaria de Vigilância em Saúde. Mapa de risco da malária por município de infecção [Internet]. Brasília: Ministério da Saúde; 2015 [cited 2017 Sep 20]. Available from:

http://portalarquivos.saude.gov.br/images/pdf/2017/fevereiro/32/Mapa-derisco_malaria_2015.pdf

53. Cesário M, Cesário RR. Malária, Amazônia e desenvolvimento. Sci Am Bras. 2006;46:54-5.

54. Brasil. Ministério da Saúde. Secretaria de Vigilância em Saúde. Lista de municípios pertencentes às áreas de risco ou endêmicas para malária. Brasília: Ministério da Saúde; 2016. 9 p.

55. Brasil. Ministério da Saúde. Secretaria de Vigilância em Saúde. Série histórica 2017 [Internet]. Brasília: Ministério da Saúde; 2017 [cited 2017 Sep 20].

Available from: http://portalsaude.saude.gov.br/index.php/o-

ministerio/principal/leia-mais-o-ministerio/662-secretaria-svs/vigilancia-de-a-az/malaria/11346-situacao-epidemiologica-dados

56. Brasil. Ministério da Saúde. Secretaria de Vigilância em Saúde. Série histórica 2014 [Internet]. Brasília: Ministério da Saúde; 2014 [cited 2017 Sep 20].

Available from: http://portalsaude.saude.gov.br/index.php/o-

ministerio/principal/leia-mais-o-ministerio/662-secretaria-svs/vigilancia-de-a-az/malaria/11346-situacao-epidemiologica-dados

57. Brasil. Ministério da Saúde. Secretaria de Vigilância em Saúde. Sistema de Vigilância Epidemiológica da Malária-SIVEP-Malária [Internet]. Brasília:

Ministério da Saúde; 2012. Available from:

http://portalweb04.saude.gov.br/sivep_malaria/default.asp

58. Brabin BJ. An analysis of malaria in pregnancy in Africa. Bull World Health Organ [Internet]. 1983. Jan;61(6):1005-16. Available from:

http://www.pubmedcentral.nih.gov/articlerender.fcgi?artid=2536236\&tool=pmce ntrez\&rendertype $=$ abstract

59. Dellicour S, Tatem AJ, Guerra C a, Snow RW, ter Kuile FO. Quantifying the number of pregnancies at risk of malaria in 2007: a demographic study. PLoS Med [Internet]. 2010 Jan [cited $2011 \mathrm{Jul}$ 30];7(1):e1000221. Available from: http://www.pubmedcentral.nih.gov/articlerender.fcgi?artid=2811150\&tool=pmce ntrez\&rendertype $=$ abstract

60. Chagas ECDS, Nascimento CT Do, Santana Filho FS De, Bôtto-Menezes $\mathrm{CH}$, Martinez-Espinosa FE. Malária durante a gravidez: efeito sobre o curso da gestação na região amazônica. Rev Panam Salud Pública [Internet]. 2009 Sep;26(3):203-8. Available from:

http://www.scielosp.org/scielo.php?script=sci_arttext\&pid=S102049892009000900003\&lng=pt\&nrm=iso\&tlng=pt

61. World Health Organization. The World Health Report 2005: make every mother and child count [Internet]. Geneva: World Health Organization; 2005 [cited 2017 Sep 20]. Available from: http://www.who.int/whr/2005/whr2005_en.pdf?ua=1

62. World Health Organization. World Malaria Report 2015. Geneva: World Health 
Organization; 2015. 280 p.

63. Nosten F, ter Kuile F, Maelankirri L, Decludt B, White NJ. Malaria during pregnancy in an area of unstable endemicity. Trans R Soc Trop Med Hyg [Internet]. 1991 [cited 2012 Feb 11];85(4):424-9. Available from:

http://www.ncbi.nlm.nih.gov/pubmed/1836685

64. Menendez C. Malaria during pregnancy: a priority area of malaria research and control. Parasitol Today [Internet]. 1995 May;11(5):178-83. Available from: http://www.ncbi.nlm.nih.gov/pubmed/15275350

65. Baird JK. Neglect of Plasmodium vivax malaria. Trends Parasitol [Internet]. 2007 Nov [cited 2011 Jun 23];23(11):533-9. Available from: http://www.ncbi.nlm.nih.gov/pubmed/17933585

66. Nosten F, Rogerson SJ, Beeson JG, McGready R, Mutabingwa TK, Brabin B. Malaria in pregnancy and the endemicity spectrum: what can we learn? Trends Parasitol. 2004;20(9):425-32.

67. Rogerson SJ, Hviid L, Duffy PE, Leke RFG, Taylor DW. Malaria in pregnancy: pathogenesis and immunity. Lancet Infect Dis [Internet]. 2007 [cited 2012 Mar 2];7(2):105-117. Available from:

http://www.sciencedirect.com/science/article/pii/s1473-3099(07)70022-1

68. Rasheed FN, Bulmer JN, Dunn DT, Menendez C, Jawla MF, Jepson A, et al. Suppressed peripheral and placental blood lymphoproliferative responses in first pregnancies: relevance to malaria. Am J Trop Med Hyg [Internet]. 1993 Feb;48(2):154-60. Available from:

http://www.ncbi.nlm.nih.gov/pubmed/8447517

69. Walter PR, Garin Y, Blot P. Placental pathologic changes in malaria. A histologic and ultrastructural study. Am J Pathol. 1982;109(3):330-42.

70. Beeson JG, Amin N, Kanjala M, Rogerson SJ. Selective Accumulation of Mature Asexual Stages of Plasmodium falciparum-Infected Erythrocytes in the Placenta. Society. 2002;70(10):5412-5.

71. Nwagha UI, Ugwu VO, Nwagha TU, Anyaehie BU. Asymptomatic Plasmodium parasitaemia in pregnant Nigerian women: almost a decade after Roll Back Malaria. Trans R Soc Trop Med Hyg [Internet]. 2009 Jan [cited 2013 Oct 25];103(1):16-20. Available from: http://www.ncbi.nlm.nih.gov/pubmed/18783809

72. Rogerson SJ, Chaiyaroj SC, Ng K, Reeder JC, Brown GV. Chondroitin sulfate A is a cell surface receptor for Plasmodium falciparum-infected erythrocytes. J Exp Med [Internet]. 1995 [cited 2012 Feb 27];182(1):15-20. Available from: http://jem.rupress.org/content/182/1/15.abstract

73. Fried M, Duffy PE. Adherence of Plasmodium falciparum to chondroitin sulfate $A$ in the human placenta. Science (80- ) [Internet]. 1996 Jun 7 [cited 2011 Dec 10];272(5267):1502-4. Available from:

http://www.ncbi.nlm.nih.gov/pubmed/8633247

74. Nosten F, McGready R, Simpson JA, Thwai KL, Balkan S, Cho T, et al. Effects of Plasmodium vivax malaria in pregnancy. Lancet [Internet]. 1999 Aug 14 [cited 2011 Dec 11];354(9178):546-9. Available from: 
http://www.ncbi.nlm.nih.gov/pubmed/10470698

75. Rogerson SJ, Pollina E, Getachew A, Tadesse E, Lema VM, Molyneux ME. Placental monocyte infiltrates in response to Plasmodium falciparum malaria infection and their association with adverse pregnancy outcomes. Am J Trop Med Hyg [Internet]. 2003/01/31. 2003 [cited 2012 Mar 2];68(1):115-119. Available from: http://www.ajtmh.org/content/68/1/115.short

76. Abrams ET, Brown H, Chensue SW, Turner GD, Tadesse E, Lema VM, et al. Host response to malaria during pregnancy: placental monocyte recruitment is associated with elevated beta chemokine expression. J Immunol. 2003/02/21. 2003;170(5):2759-64.

77. Kochar DK, Saxena V, Singh N, Kochar SK, Kumar SV, Das A. Plasmodium vivax malaria. Emerg Infect Dis [Internet]. 2005 Jan [cited $2011 \mathrm{Dec}$ 7];11(1):132-4. Available from: http://www.ncbi.nlm.nih.gov/pubmed/15705338

78. Rogerson SJ, Mkundika P, Maxwell K, Kanjala MK. Diagnosis of Plasmodium falciparum Malaria at Delivery : Comparison of Blood Film Preparation Methods and of Blood Films with Histology Diagnosis of Plasmodium falciparum Malaria at Delivery : Comparison of Blood Film Preparation Methods and of Blood Film. J Clin Microbiol. 2003;41(4):1370-4.

79. Brasil. Ministério da Saúde. Secretaria de Vigilância em Saúde. Importância da gota espessa nas consultas de pré-natal [Internet]. Programa Nacional de Controle da Malária Coordenador Geral, Nota Técnica. Brasília: Ministério da Saúde; 2014 [cited 2017 Aug 14]. Available from:

http://189.28.128.100/dab/docs/portaldab/notas_tecnicas/nota_informativa_con junta.pdf

80. Brasil. Ministério da Saúde. Guia prático de tratamento da malária no Brasil. Brasília: Ministério da Saúde; 2010. 38 p.

81. Carmona-fonseca J, Maestre-b A. Incidence of gestational, congenital and placental malaria in Urabá (Antioquia , Colombia), 2005-2007. Rev Colomb Obstet Ginecol. 2009;60(1):2005-7.

82. Lacerda MVG, Mourão MPG, Alexandre M, Siqueira AM, Magalhães BML, Martinez-Espinosa FE, et al. Understanding the clinical spectrum of complicated Plasmodium vivax malaria: a systematic review on the contributions of the Brazilian literature. Malar J [Internet]. 2012 Jan;11:12. Available from:

http://www.pubmedcentral.nih.gov/articlerender.fcgi $?$ artid=3268102\&tool=pmce ntrez\&rendertype $=$ abstract

83. Tiono AB, Ouedraogo A, Bougouma EC, Diarra A, Konaté AT, Nébié I, et al. Placental malaria and low birth weight in pregnant women living in a rural area of Burkina Faso following the use of three preventive treatment regimens. Malar J [Internet]. 2009 Jan [cited 2011 Nov 8];8:224. Available from: http://www.pubmedcentral.nih.gov/articlerender.fcgi ?artid=2768741\&tool=pmce ntrez\&rendertype $=$ abstract

84. Luxemburger C, McGready R, Kham A, Morison L, Cho T, Chongsuphajaisiddhi $\mathrm{T}$, et al. Effects of malaria during pregnancy on infant mortality in an area of low malaria transmission. Am J Epidemiol [Internet]. 
2001 Sep 1;154(5):459-65. Available from:

http://www.ncbi.nlm.nih.gov/pubmed/11532788

85. Steketee RW, Nahlen BL, Parise ME, Menendez C. The burden of malaria in pregnancy in malaria-endemic areas. Am J Trop Med Hyg [Internet]. 2001;64(1-2 Suppl):28-35. Available from:

http://www.ncbi.nlm.nih.gov/pubmed/11425175

86. Christensen DL, Kapur A, Bygbjerg IC. Physiological adaption to maternal malaria and other adverse exposure: Low birth weight , functional capacity , and possible metabolic disease in adult life. Int $\mathrm{J}$ Gynecol Obstet [Internet]. 2011;115:S16-9. Available from: http://dx.doi.org/10.1016/S00207292(11)60006-4

87. Guyatt HL, Snow RW. Impact of Malaria during Pregnancy on Low Birth Weight in Sub-Saharan Africa. Society. 2004;17(4).

88. Quintero JP, Siqueira AM, Tobón A, Blair S, Moreno A, Arévalo-Herrera M, et al. Malaria-related anaemia: a Latin American perspective. Mem Inst Oswaldo Cruz [Internet]. 2011 Aug;106 Suppl:91-104. Available from:

http://www.ncbi.nlm.nih.gov/pubmed/21881762

89. Silver KL, Zhong K, Leke RGF, Taylor DW, Kain KC. Dysregulation of angiopoietins is associated with placental malaria and low birth weight. Beeson JG, editor. PLoS One [Internet]. 2010 Jan [cited 2011 Sep 22];5(3):e9481.

Available from:

http://www.pubmedcentral.nih.gov/articlerender.fcgi?artid=2830425\&tool=pmce ntrez\&rendertype $=$ abstract

90. Desai M, ter Kuile FO, Nosten F, McGready R, Asamoa K, Brabin B, et al. Epidemiology and burden of malaria in pregnancy. Lancet Infect Dis. 2007;7(2):93-104.

91. Jarude R, Trindade R, Tavares-Neto J. Malária em grávidas de uma maternidade pública de Rio Branco (Acre, Brasil). Rev Bras Ginecol Obs [Internet]. 2003 [cited 2014 Apr 24];25(3):149-54. Available from: http://www.scielo.br/pdf/rbgo/v25n3/16616.pdf

92. Dellicour S, Tatem AJ, Guerra CA, Snow RW, Ter Kuile FO. Quantifying the number of pregnancies at risk of malaria in 2007: A demographic study. PLoS Med. 2010;7(1):1-10.

93. Muehlenbachs A, Fried M. A novel histological grading scheme for placental malaria applied in areas of high and low malaria transmission. $J$ Infect [Internet]. 2010 [cited 2012 Mar 2];202(10):1608-16. Available from: http://jid.oxfordjournals.org/content/202/10/1608.short

94. Ismail MR, Ordi J, Menendez C, Ventura PJ, Aponte JJ, Kahigwa E, et al. Placental pathology in malaria: a histological, immunohistochemical, and quantitative study. Hum Pathol [Internet]. 2000 Jan [cited 2011 Sep 1];31(1):85-93. Available from: http://www.ncbi.nlm.nih.gov/pubmed/10665918

95. Geva E, Ginzinger DG, Zaloudek CJ, Moore DH, Byrne A, Jaffe RB. Human placental vascular development: vasculogenic and angiogenic (branching and nonbranching) transformation is regulated by vascular endothelial growth factor-A, angiopoietin-1, and angiopoietin-2. J Clin Endocrinol Metab [Internet]. 
2002 Sep [cited 2011 Dec 10];87(9):4213-24. Available from: http://www.ncbi.nlm.nih.gov/pubmed/12213874

96. Muehlenbachs A, Mutabingwa TK, Edmonds S, Fried M, Duffy PE. Hypertension and maternal-fetal conflict during placental malaria. PLoS Med [Internet]. 2006 Nov [cited 2011 Sep 24];3(11):e446. Available from: http://www.pubmedcentral.nih.gov/articlerender.fcgi?artid=1635741\&tool=pmce ntrez\&rendertype $=$ abstract

97. Conroy AL, Liles WC, Molyneux ME, Rogerson SJ, Kain KC. Performance Characteristics of Combinations of Host Biomarkers to Identify Women with Occult Placental Malaria: A Case-Control Study from Malawi. PLoS One [Internet]. 2011 [cited 2012 Mar 2];6(12):e28540. Available from: http://dx.plos.org/10.1371/journal.pone.0028540

98. Walther B, Miles DJC, Crozier S, Waight P, Palmero MS, Ojuola O, et al. Placental malaria is associated with reduced early life weight development of affected children independent of low birth weight. Malar J [Internet]. 2010 Jan;9:16. Available from:

http://www.pubmedcentral.nih.gov/articlerender.fcgi?artid=2841609\&tool=pmce ntrez\&rendertype $=$ abstract

99. Umbers AJ, Boeuf P, Clapham C, Stanisic DI, Baiwog F, Mueller I, et al. Placental Malaria-Associated Inflammation Disturbs the Insulin-like Growth Factor Axis of Fetal Growth Regulation. 2011;203:561-9.

100. Jones HN, Powell TL, Jansson T. Regulation of placental nutrient transport--a review. Placenta [Internet]. 2007 [cited 2012 Mar 26];28(8-9):763-74. Available from: http://www.ncbi.nlm.nih.gov/pubmed/17582493

101. Freemark M. Regulation of maternal metabolism by pituitary and placental hormones: roles in fetal development and metabolic programming. Horm Res [Internet]. 2006;65 Suppl 3(suppl 3):41-9. Available from: http://www.ncbi.nlm.nih.gov/pubmed/16612113

102. Stevenson DK, Verter J, Fanaroff a a, Oh W, Ehrenkranz R a, Shankaran S, et al. Sex differences in outcomes of very low birthweight infants: the newborn male disadvantage. Arch Dis Child Fetal Neonatal Ed [Internet]. 2000 Nov;83(3):F182-5. Available from: http://www.pubmedcentral.nih.gov/articlerender.fcgi?artid=1721180\&tool=pmce ntrez\&rendertype=abstract

103. Clifton VL. Review: Sex and the human placenta: mediating differential strategies of fetal growth and survival. Placenta [Internet]. 2010 Mar [cited 2011 Aug 17];24(31):S33-9. Available from: http://www.ncbi.nlm.nih.gov/pubmed/20004469

104. Cottrell G, Mary J-Y, Barro D, Cot M. The importance of the period of malarial infection during pregnancy on birth weight in tropical Africa. Am J Trop Med Hyg [Internet]. 2007 May;76(5):849-54. Available from: http://www.ncbi.nlm.nih.gov/pubmed/17488903

105. Brasil. Ministério da Saúde. Organização Pan-Americana da Saúde. Fundação Oswaldo Cruz. A experiência brasileira em sistemas de informação em saúde. Brasília: Ministério da Saúde; 2009. 148 p. 
106. Silva GF, Aidar T, Mathias TA de F. Qualidade do Sistema de Informações de Nascidos Vivos no Estado do Paraná, 2000 a 2005. Rev da Esc EnfermagemUSP. 2011;45(1):79-86.

107. Silveira MF, Santos IS, Matijasevich A, Malta DC, Duarte EC. Nascimentos pré-termo no Brasil entre 1994 e 2005 conforme o Sistema de Informações sobre Nascidos Vivos (SINASC). Cad Saúde Pública. 2009;25(6):1267-75.

108. Frias PG, Pereira PMH, Andrade CLT, Lira PIC, Szwarcwald CL. Avaliação da adequação das informações de mortalidade e nascidos vivos no Estado de Pernambuco , Brasil. Cad Saúde Pública. 2010;26(4):671-81.

109. Guimarães EA de A, Loyola Filho Al de, Hartz ZM de A, Meira AJ de, Luz ZMP. A descentralização do SINASC e a completitude das variáveis da declaração de nascido vivo em municípios mineiros de 1998 a 2005. Rev Bras Crescimento Desenvolv Hum. 2011;21(3):832-40.

110. Paiva NS, Coeli CM, Moreno AB, Guimarães RM, Camargo Júnior KR. Sistema de informações sobre nascidos vivos: um estudo de revisão. Ciência e Saúde Coletiva. 2011;16(1):1211-20.

111. Luquetti DV, Koifman RJ. Qualidade da notificação de anomalias congênitas pelo Sistema de Informações sobre Nascidos Vivos (SINASC): estudo comparativo nos anos 2004 e 2007. Cad Saúde Pública. 2010;26(9):1756-65.

112. Brasil. Ministério da Saúde. Secretaria de Vigilância em Saúde. Departamento de Análise de Situação de Saúde. Manual de instruções para o preenchimento da declaração de nascido vivo. 4 ed. Brasília: Ministério da Saúde; 2010. 26 p.

113. Brasil. Ministério da Saúde. Fundação Nacional de Saúde. Manual de procedimentos do sistema de informações sobre nascidos vivos. 1ed. Brasília: Ministério da Saúde; 2001. 32 p.

114. Braz, Rui Moreira, Andreozzi, Valeska Lima, \& Kale PL. Detecção precoce de epidemias de malária no Brasil: uma proposta de automação. Epidemiol Serv Saúde. 2006;15(2):21-33.

115. Brasil. Ministério da Saúde. Secretaria de Vigilância em Saúde. Malária [Internet]. Brasília: Ministério da Saúde; 2014 [cited 2017 Sep 6]. Available from: http://portalsaude.saude.gov.br/index.php/oministerio/principal/secretarias/svs/malaria

116. Brasil. Ministério da Saúde. Secretaria de Vigilância em Saúde. Malária. Brasília: Ministério da Saúde; 2014.

117. Oliveira-ferreira J, Lacerda MVG, Brasil P, Ladislau JLB, Tauil PL, Danielribeiro CT. Malaria in Brazil : an overview Review. Malar J. 2010;1-15.

118. Wiefels A, Wolfarth-Couto B, Filizola N, Durieux L, Mangeas M. Accuracy of the malaria epidemiological surveillance system data in the state of Amazonas. Acta Amaz [Internet]. 2016 Dec;46(4):383-90. Available from: http://www.scielo.br/scielo.php?script=sci_arttext\&pid=S0044$59672016000400383 \&$ Ing=en\&tIng=en

119. Rijken MJ, Papageorghiou AT, Thiptharakun S, Kiricharoen S, Dwell SLM, Wiladphaingern J, et al. Ultrasound Evidence of Early Fetal Growth Restriction after Maternal Malaria Infection. PLoS One. 2012 Feb;7(2):e31411. 
120. Desai M, ter Kuile FO, Nosten F, McGready R, Asamoa K, Brabin B, et al. Epidemiology and burden of malaria in pregnancy. Lancet Infect Dis [Internet]. $2007 \mathrm{Feb} ; 7(2): 93-104$. Available from:

http://www.ncbi.nlm.nih.gov/pubmed/17251080

121. Brasil. Ministério do Planejamento, Desenvolvimento e Gestão. Instituto Brasileiro de Geografia e Estatística. Cidades [Internet]. Rio de Janeiro: Ministério do Planejamento, Desenvolvimento e Gestão; 2016 [cited 2017 Oct 20]. Available from: http://cod.ibge.gov.br/2v9tk

122. Acre (Estado), Secretaria de Estado de Planejamento. Acre em Números 2011. Rio Branco: Secretaria de Estado de Planejamento; 2011. 103 p.

123. Lucchi NW, Narayanan J, Karell M a., Xayavong M, Kariuki S, DaSilva AJ, et al. Molecular Diagnosis of Malaria by Photo-Induced Electron Transfer Fluorogenic Primers: PET-PCR. PLoS One. 2013;8(2):1-7. 